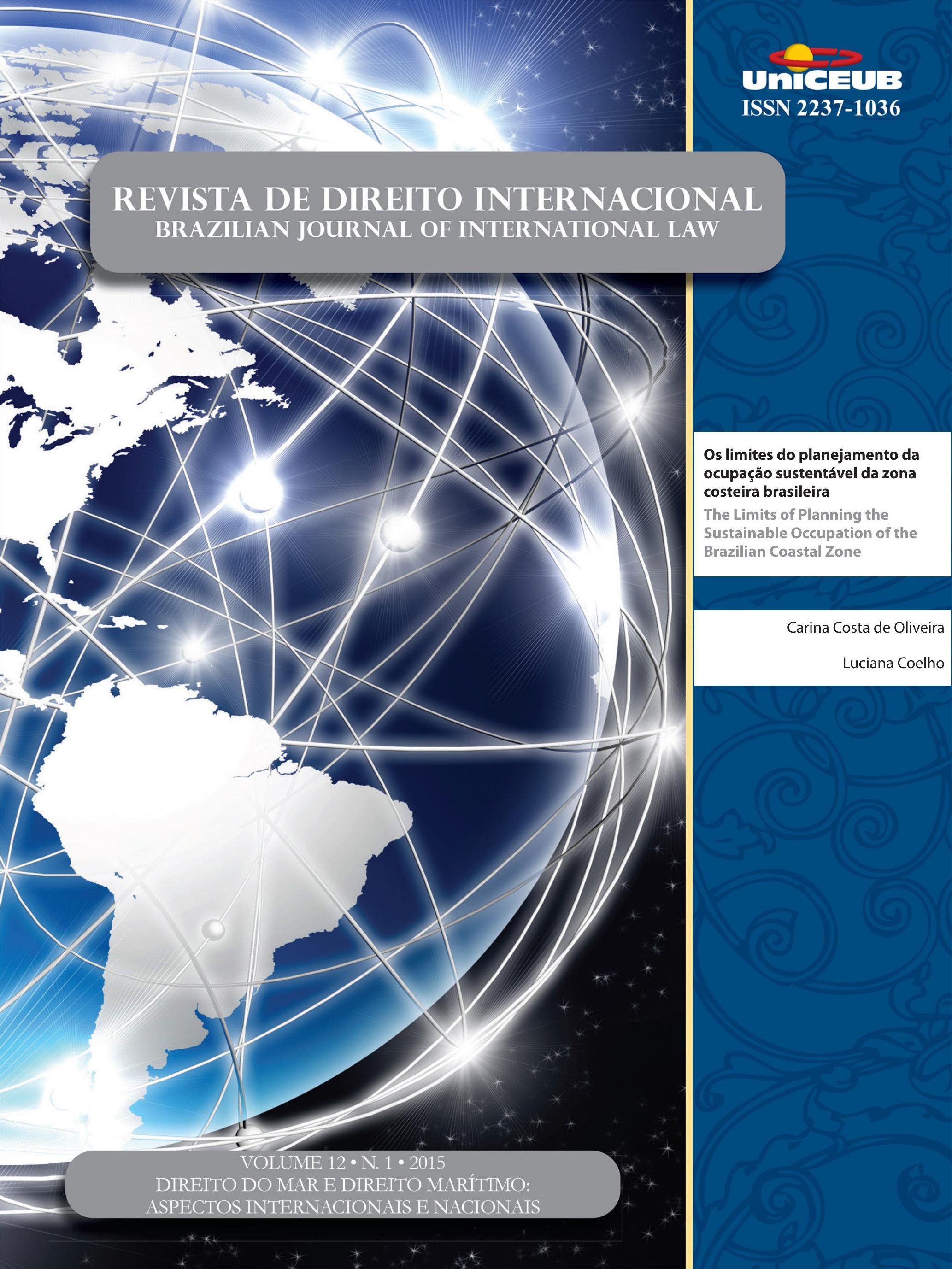




\section{Sumário}

\section{Crônicas}

CRôNICAS DA ATUALIDADE do DiREITO INTERNACIONAL ........................................................ 2

Nitish Monebhurrun (org.)

Towards a european regulation of the importation of conflict minerals?..... 2

Nitish Monebhurrun

Keeping up with the terrorists: the EU's proposed Passenger Name Records (PNR) Directive \& european security

Eshan Dauhoo

A histórica reaproximação de Cuba e EUA

Erika Braga

A contextualização da atual reivindicação da Grécia para receber indenizações por atos da Alemanha durante a Segunda Guerra Mundial . .10

Natália da Silva Gonçalves

José Eduardo Paiva Miranda de Siqueira

Crônicas da jurisprudência do Direito Internacional (CIJ/ITLOS): Decisões da Corte Internacional de Justiça e do Tribunal Internacional Sobre o Direito do Mar .14

Nitish Monebhurrun (Org.)

Corte Internacional de Justiça

Estudo da decisão da Corte Internacional de Justiça no caso Croácia v. Servia (03/02/2015) .14

Liziane Paixão Silva Oliveira e Maria Edelvacy Marinho

Questões relacionadas com a apreensão e detenção de certos documentos e dados: (Timor Leste c. Austrália) - O reconhecimento do retorno de uma relação amigável entre Timor-Leste e Austrália e a nova decisão da CIJ, 6 de maio de 2015 . 20

Gleisse Ribeiro Alves

Tribunal Internacional sobre Direito do Mar

Caso da delimitação da fronteira marítima entre o Gana e a Costa do Marfim no Oceano Atlântico: medidas cautelares $(25 / 04 / 2015)$

Nitish Monebhurrun

Comentário à Opinião Consultiva 21 do Tribunal Internacional para o Direito Do Mar [02/04/2015] (Responsabilidade do Estado de Bandeira pela pesca ilícita, não declarada ou não regulamentada) ...............25

Carina Costa de Oliveira 
CRÔNICAS DO DIREITO INTERNACIONAL DOS INVESTIMENTOS

Nitish Monebhurrun (Org.)

A inclusão da responsabilidade social das empresas nos novos Acordos de Cooperação e de Facilitação dos Investimentos do Brasil: uma revolução 33

Nitish Monebhurrun

\section{O Direito do Mar Perante as JuRisdições INTERnacionais}

CoAstal States' Rights IN THE MARITIME AREAS UNDER UNCLOS .40 Tullio Treves

TACKling illegal, unregulated And unReported Fishing: THE ITLOS Advisory OpINION on Flag State Responsibility for IUU fishing AND THE PRINCiple of DUE DiligenCE ...50 Victor Alencar Mayer Feitosa Ventura

REFLEXões PROVENIENTES do DisSENSO: UMA ANÁLISE CRÍtica A RESPEITO do CASO Austrália versus Japão Perante a Corte InTERnacional de JustiçA .......................................68 Luciana Ferna ndes Coelho

Os TRATADOS INTERNACIONAIS DE DIREITO DO MAR E SEUS EFEITOS SOBRE TERCEIROS ESTADOS ..... 86 Tiago V. Zanella

\section{InStRumentos JURÍdicos PARA A GeStÃo do MAR}

OS LIMITES DOS TERMOS BEM PÚBLICO MUNDIAL, PATRIMÔNIO COMUM DA HUMANIDADE E BENS COMUNS PARA DELIMITAR AS OBRIGAÇÕES DE PRESERVAÇÃO DOS RECURSOS MARINHOS 109 Carina Costa de Oliveira e Sandrine Maljean-Dubois

Os limites do PLANEJAMENTO DA OCUPAÇÃo SUSTENTÁVEL DA ZONA COSTEIRA BRASILEIRA ... 126 Carina Costa de Oliveira e Luciana Coelho

CORRENDO PARA O MAR NO ANTROPOCENO: A COMPLEXIDADE DA GOVERNANÇA DOS OCEANOS E A ESTRATÉGIA BRASILEIRA DE GESTÃO DOS RECURSOS MARINHOS 
A comissão de limites da Plataforma continental (CLPC) E Os DESAFios Na delineaÇÃo DAS PLATAFORMAS CONTINENTAIS ESTENDIDAS................................................... 170

Alexandre Pereira da Silva

\section{A PROTEÇÃo DO MEIO AMBIENTE MARINHO}

O gRANDE JOGo do ÁrTiCo: REFLEXões COM BASE NA PERSPECTIVA DE EXPLORAÇão ECONÔMICA

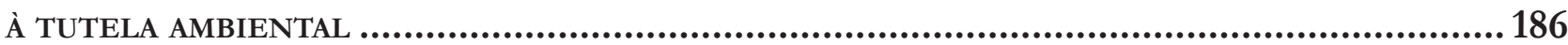

Fernando Rei e Valeria Cristina Farias

Instrumentos Públicos e Privados para a reparação do dano ambiental causado por DERRAMAMENTO DE ÓLEO NO MAR SEM ORIGEM DEFINIDA: AS MANCHAS ÓRFÃS

Renata Brockelt Giacomitti e Katya R. Isaguirre-Torres

O DIREITO INTERNACIONAL PRIVADO E A RESPONSABILIDADE CIVIL EXTRACONTRATUAL POR DANOS AMBIENTAIS CAUSADOS POR TRANSPORTES MARÍTIMOS À LUZ DO DIREITO BRASILEIRO ....... 217 Inez Lopes

A NECESSIDADE DE REPENSAR OS MECANISMOS DE RESPONSABILIDADE AMBIENTAL EM CASO DE riscos de VAZamento de PETRóleo Na Zona Econômica Exclusiva do BrasiL

Marcelo D. Varella

\section{Problemáticas do Direito Marítimo}

A FisCALIZAÇão SANitÁRIA DAS EMBARCAÇÕES EM ÁGUAS JURISDICIONAIS BRASILEIRAS: NOTAS aCERCA da (IN)efetividade da Súmula 50 da AGU

Joedson de Souza Delgado e Ana Paula Henriques da Silva

A IMO E A REPRESSÃo AO ROUBO ARMADO CONTRA NAVIOS: DA RETÓRICA INTERNACIONAL À COOPERAÇÃO REGIONAL

André Panno Beirão e Charles Pacheco Piñon

\section{O Direito do Mar diante da Pirataria}

O DIREITO INTERNACIONAL EM FACE DA PIRATARIA EM ALTO-MAR: UMA PERSPECTIVA CRÍTICA.289 Maiquel Ângelo Dezordi Wermuth e Rafaela Correa 
Pirataria marítima: A EXPERIÊnCIA Somália

Eduardo Augusto S. da C. Schneider

\section{Temas Gerais}

DRAWING THE LINE: ADDRESSING ALLEGATIONS OF UNCLEAN HANDS IN INVESTMENT ARBITRATION*

Mariano de Alba

Para Que Serve a história do Direito internacional?

George Rodrigo Bandeira Galindo

As interferências entre a Política Externa e de Segurança Comum Europeia (Pesc) e O DiREITO DAS NaÇões UNIDAS

Leonardo de Camargo Subtil

Introdução Às regras de aplicaÇão da Convenção da ONU Sobre Contratos de ComPRA E VENDA INTERNACIONAL DE MERCADORIAS E O DIREITO INTERNACIONAL PRIVADO BRASI-

LEIRO 380

Paul Hugo Weberbauer e Eugênia Cristina Nilsen Ribeiro Barza

A REgulaÇÃo das EMPRESAS TRANSNACIONAIS ENTRE AS ORDENS JURÍDICAS ESTATAIS E NÃO ESTATAIS.

Mateus de Oliveira Fornasier e Luciano Vaz Ferreira

OUtLAWING HATE SPEECH IN DEMOCRATIC STATES: THE CASE AGAINST THE INHERENT LimitAtions doctrine concerning Article 10 (1) of the European Convention on Human

Rights 416

Stefan Kirchner 


\title{
Os limites do planejamento da ocupação sustentável da zona costeira brasileira*
}

\author{
The Limits of Planning the Sustainable \\ Occupation of the Brazilian Coastal Zone
}

\author{
Carina Costa de Oliveira** \\ Luciana Coelho***
}

\section{Resumo}

Há limites institucionais e normativos no planejamento da ocupação sustentável da zona costeira brasileira. Embora exista demasiada quantidade de normas e instituições voltadas para o gerenciamento dessa área, a ocupação desta é realizada desordenadamente. Em relação à faixa terrestre da zona costeira, a análise da atividade de construção civil demonstrou a ausência de critérios objetivos precisos que determinem a competência para licenciar e para fiscalizar as atividades na área. A propósito da faixa marítima, a gestão pela Autoridade Marítima não garante a gestão dos usos múltiplos da zona costeira. Com relação aos limites normativos, a pluralidade de termos e institutos aplicáveis à zona costeira, como bem comum de uso do povo, bem da União, terreno de marinha e patrimônio nacional, resulta na interpretação imprecisa da natureza jurídica da zona costeira. Lacunas e omissões relevantes, como a previsão de uma restrição geral de construir em determinada extensão do litoral nacional, demonstram o descuido dosentes federativos na busca pela melhor administração e normatização da área. A planificação do espaço marítimo brasileiro poderá ocorrer somente após sanados os diversos limites institucionais e normativos presentes e incrustados na ocupação da zona costeira brasileira.

Palavras-chave: Zona costeira. Planejamento. Ocupação. Construções. Proteção do meio ambiente.

\section{Abstract}

There are institutional and normative limits when planning the sustainable occupation of the Brazilian coastal zone. Although there are many norms and institutions focused on the management of this area, its occupation is carried out disorderly. Regarding the terrestrial part of the coastal zone, the analysis of construction activities developed in the Brazilian coastal zone reveals a lack of objective criteria to determine the competent authority to grant permission for this activity and to supervise the activities performed in the area. For the maritime part, the management by the Maritime Authority does not guarantee the management of the multiple uses of the coastal zone. Concerning the normative limits, the large amount of legal concepts that can be applied to the coastal zone, such as commons, bem 
da União, terreno de marinha and patrimônio nacional, results in an inaccurate interpretation of the legal nature of the coastal zone. Significant gaps and omissions, such as lack of a general restriction to build a certain extension of the coastal zone, expresses the disregard of all federal entities in the pursuit of a better management and regulation of this zone. In this context, the Brazilian maritime planning can only be made after solving out the various institutional and regulatory problems related to the occupation of the Brazilian coastal zone.

Keywords: Coastal zone. Construction. Occupation. Maritime planning. Environmental protection.

\section{INTRODUÇÃo}

O planejamento da ocupação sustentável da zona costeira brasileira é realizado de forma desordenada em razão de limites institucionais e normativos existentes no sistema jurídico brasileiro. Com mais de $8.000 \mathrm{~km}$ de litoral, as atividades de exploração do território marítimo brasileiro não são realizadas de forma hormoniosa com a proteção ao meio ambiente, tanto na faixa terrestre como na faixa marítima da zona costeira. A gestão dessa região está prevista na Lei n. ${ }^{\circ}$ 7.661/1988 e no Decreto n. ${ }^{\circ}$ 5.300/2004, no entanto, a gestão sustentável ainda não foi implementada. Questões como a erosão do solo, a poluição e a exploração excessiva dos recursos vivos e não vivos são algumas das consequências resultantes do impacto que atividades como construções irregulares na zona costeira podem causar. Nesse contexto, é relevante: definir a zona costeira brasileira, o litoral e a zona marítima; demonstrar a inexistência da planificação do espaço marítimo no Brasil; e delimitar as atividades de exploração que serão analisadas neste estudo cujo objetivo consiste em demonstrar os limites institucionais e normativos para alcançar um planejamento do território marítimo nacional sustentável.

A zona costeira brasileira é definida como o espaço geográfico de interação entre ar, mar e terra, incluindo os recursos renováveis ou não, que se estende em uma faixa terrestre e uma faixa marítima ${ }^{1}$. Trata-se de região

1 BRASIL. Lei $n^{\circ} 7.661$ de 16 de maio de 1998. Disponível em: $<$ http://www.planalto.gov.br/ccivil_03/leis/17661.htm>. Acesso em: 04 ago. 2015; BRASIL. Decreto n 5.300, de 07 de dezembro de 2004. Disponível em: < http://www.planalto.gov.br/ccivil_03/_ato20042006/2004/decreto/D5300.htm>. Acesso em: 10 jul. 2014. Cf. FREITAS, Mariana Almeida Passos de. Zona Costeira e Meio Am- vulnerável, especialmente pelo contingente populacional que habita a região, pela rica concentração de fauna e flora explorável economicamente e pelo número intenso de atividades econômicas ali desenvolvidas. ${ }^{2}$ Essa região é constitucionalmente tutelada como patrimônio nacional, cujo desenvolvimento deve ocorrer de forma sustentável. $^{3}$

A faixa marítima é delimitada com a dimensão de 12 milhas náuticas, contadas da linha de base estabelecida, de acordo com a Convenção das Nações Unidas sobre o Direito do Mar de 1982 (UNCLOS), enquanto a faixa terrestre possui largura variável ${ }^{4}$. Esta é composta por uma área indicada na Relação de Municípios abrangidos pela faixa terrestre da zona costeira, que deve ser periodicamente revisada pelo Ministério do Meio Ambiente (MMA) $)^{5}$, compreendendo mais ou menos 395 Municípios, distribuídos em 17 estados costeiros ${ }^{6}$. Esses Municípios sofrem influência dos fenômenos ocorrentes na zona costeira, podendo ser ou não defrontantes com o mar, conforme parâmetros estabelecidos no Decreto $5.300 / 2004 .^{7}$

biente. Curitiba: Juruá, 2005. p. 23-32. Cf. BRASIL. Lei no 7.661 de 16 de maio de 1998. Disponível em: <http://www.planalto.gov.br/ ccivil_03/leis/17661.htm>. Acesso em: 04 ago. 2015. artigo 2º parágrafo único; Cf. BRASIL. Comissão Interministerial para os Recursos do Mar. Resolução no 01, de 21 de novembro de 1990. Disponível em: <https://www.mar.mil.br/secirm/document/ataseresolucoes/ resolucao-1-1994.pdf>. Acesso em: 05 ago. 2015.

2 FREITAS, Vladimir Passos de; FREITAS, Dario Almeida Passos de. A proteção do meio ambiente na zona costeira. In: GRANZIERA, Maria Luiza Machado; GONÇALVES, Alcindo (Org.). Os problemas da zona costeira no Brasil e no mundo. Santos: Universitária Leopoldianum, 2012. p. 257-277. p. 258.

3 BRASIL. Constituição (1988). Constituição da República Federativa do Brasil. Disponível em: <http://www.planalto.gov.br/ ccivil_03/constituicao/constituicao.htm>. Acesso em: 05 ago. 2014. BRASIL. Lei no 12.651 de 25 de maio de 2012. Disponível em: <http://www.planalto.gov.br/ccivil_03/_Ato2011-2014/2012/ Lei/L12651.htm\#art83>. Acesso em: agosto 2014.

4 Sobre o tema ver: SILVA, Solange Teles da. Planejamento urbano na Zona Costeira. In: Compedi. In: CONGRESSO NACIONAL DO CONPEDI, 14., 2005, Fortaleza. Anais eletrônico... Manaus: CONPEDI, 2006. Disponível em: http://www.conpedi.org.br/manaus/ arquivos/anais/XIVCongresso/151.pdf. Acesso em: 4 ago. 2015.

5 BRASIL. Decreto n ${ }^{\circ} 5.300$, de 07 de dezembro de 2004. Disponível em: <http://www.planalto.gov.br/ccivil_03/_ato2004-2006/2004/ decreto/D5300.htm>. Acesso em: 10 jul. 2014. Parágrafo primeiro. 6 BRASIL. Ministério do Meio Ambiente. Limites da Zona Costeira. Disponível em: < http://www.mma.gov.br/gestao-territorial/gerenciamento-costeiro/a-zona-costeira-e-seus-m\%C3\%BAltiplos-usos/ caracteristicas-da-zona-costeira>. Acesso em: 09 nov. 2014.

7 BRASIL. Decreto n $n^{\circ}$ 5.300, de 07 de dezembro de 2004. Disponível em: <http://www.planalto.gov.br/ccivil_03/_ato2004-2006/2004/ decreto/D5300.htm>. Acesso em: 10 jul. 2014. Artigo 4 ${ }^{\circ}$, incisos e parágrafos. 
Embora a Relação de Municípios seja variável, não se constata uma atualização periódica da lista pelo MMA, o que resulta em uma incerteza jurídica quanto à área exata da zona costeira ${ }^{8}$. Ademais, Estados e Municípios podem requerer a inclusão ou a exclusão de sua localização na zona costeira, o que pode alterar constantemente a dimensão da área. Outras lacunas também são constantemente ressaltadas por autores ${ }^{9}$, como as incertezas relacionadas à falta de coordenação entre a gestão da zona costeira, a gestão das bacias hidrográficas e a gestão ambiental. A zona costeira tem como unidade de gestão o Município, enquanto a gestão dos recursos hídricos utiliza como unidade territorial as bacias hidrográficas. Estas, por sua vez, não consideram a influência das atividades marinhas nas partes baixas da bacia, no estuário ${ }^{10}$. No mesmo sentido, a gestão ambiental é competência de todos os entes federativos, ou seja, União, Estados e Municípios, o que muitas vezes gera conflito em razão da falta de delimitação precisa das competências ambientais normativas e administrativas relacionadas à zona costeira. ${ }^{11}$

O Decreto 5.300/2004 integra ao Plano Nacional de Gerenciamento Costeiro (PNGC) a gestão da orla marítima. Essa região está contida na zona costeira e compreende uma faixa de largura variável de interface entre o mar e a terra, cujos limites marítimos e terrestres estão previstos no art. 23 da citada norma ${ }^{12}$. A diferen-

8 Os Municípios integrantes da zona costeira estão citados no Anexo B do Plano Nacional de Gerenciamento Costeiro II (PNGC II), Resolução CIRM no 005/1997. BRASIL. Ministério do Meio Ambiente. Plano Nacional de Gerenciamento Costeiro (PNGC II). 1997. Disponível em: <http://www.mma.gov.br/images/arquivo/80033/0.PNGC-II97\%20Resolucao05_97.CIRM.pdf $>$. Acesso em: 15 out. 2014.

9 Sobre o tema ver: LOITZENBAUER, Ester; MENDES, Carlos André Bulhões. A faixa terrestre da zona costeira e os recursos hídricos na região hidrográfica do Atlântico Sul. Revista de Gestão Costeira Integrada, Lisboa, v. 14, n. 1, p. 81-94, mar. 2014. p. 84.

10 Sobre o tema ver: LOITZENBAUER, Ester; MENDES, Carlos André Bulhões. A faixa terrestre da zona costeira e os recursos hídricos na região hidrográfica do Atlântico Sul. Revista de Gestão Costeira Integrada, Lisboa, v. 14, n. 1, p. 81-94, mar. 2014. p. 84.

11 BRASIL. Constituição (1988). Constituição da República Federativa do Brasil. Disponível em: < http://www.planalto.gov.br/ccivil_03/constituicao/constituicao.htm>. Acesso em: 05 ago. 2014. Artigo 23, inciso VI.

12 "Art. 23. I - marítimo: isóbata de dez metros, profundidade na qual a ação das ondas passa a sofrer influência da variabilidade topográfica do fundo marinho, promovendo o transporte de sedimentos; II - terrestre: cinquenta metros em áreas urbanizadas ou duzentos metros em áreas não urbanizadas, demarcados na direção do continente a partir da linha de preamar ou do limite final de ecossistemas, tais como as caracterizadas por feições de praias, dunas, ciação entre a zona costeira e a orla marítima suscita questionamentos relacionados aos limites, às funções $\mathrm{e}$ às competências dessas duas áreas. A orla é objeto de planejamentos específicos, como o Projeto Orla, ${ }^{13}$ que tem como função implementar a gestão integrada da orla entre o MMA e o Ministério do Planejamento e Gestão, por meio da Secretaria do Patrimônio da União (SPU/MP). O objetivo consiste em ordenar o espaço litorâneo sob o domínio da União, organizar o seu uso múltiplo e a sua ocupação. Objetivos similares estão previstos no PNGC, por exemplo, no art. $5^{\circ}$ parágrafo $2^{\circ}$, da Lei n. ${ }^{\circ} 7.661 / 88$ que dispõe sobre a possibilidade de previsão do uso do solo, do subsolo e das águas nos planos nacional, estadual e municipal de gerenciamento costeiro, estipulando a prevalência da norma mais restritiva.

Um tema que é tratado de modo diverso por diferentes normas é a praia, componente da orla marítima. Ela é classificada como bem público de uso comum do povo, conforme art. 10 da Lei n. ${ }^{\circ} 7.661 / 98$ e pelo art. 21 do Decreto 5.300/2004. Em contrapartida, a Constituição Federal dispõe, em seu artigo 20, inciso IV, que são bens da União: "as ilhas fluviais e lacustres nas zonas limítrofes com outros países; as praias marítimas; as ilhas oceânicas e as costeiras, excluídas, destas, as que contenham a sede de Municípios, exceto aquelas áreas afetadas ao serviço público e a unidade ambiental federal, e as referidas no art. 26, II". Esses tratamentos normativos diversos podem gerar efeitos consideráveis nas autorizações de atividades que podem ou não ser realizadas na praia.

Além da Zona Costeira e da chamada Zona Litorânea, o Brasil possui vasta área oceânica delimitada internamente pela Lei 8.617/93 e coordenada pela Comissão Interministerial para os Recursos do Mar (CIRM) ${ }^{14}$. A

áreas de escarpas, falésias, costões rochosos, restingas, manguezais, marismas, lagunas, estuários, canais ou braços de mar, quando existentes, onde estão situados os terrenos de marinha e seus acrescidos" (BRASIL. Decreto n ${ }^{\circ} 5.300$, de 07 de dezembro de 2004. Disponível em: <http://www.planalto.gov.br/ccivil_03/_ato2004-2006/2004/ decreto/D5300.htm>. Acesso em: 10 jul. 2014).

13 BRASIL. Ministério do Meio Ambiente. Projeto Orla. Disponível em: <http://www.mma.gov.br/gestao-territorial/gerenciamentocosteiro/projeto-orla>. Acesso em: 18 out. 2014.

14 A CIRM foi criada pelo Decreto $\mathrm{n}^{\circ} 74.557$, competente para regular os assuntos relativos à consecução da Política Nacional para os Recursos do mar (PNRM), de acordo com o Decreto n ${ }^{\circ} 3.939$, de 26 de setembro de 2001. Brasil. Decreto no 74.557, de 12 de setembro de 1974. Disponível em: < http:/ / www.planalto.gov.br/ccivil_03/decreto/Antigos/D74557.htm>. Acesso em: 05 ago. 2015. 
chamada zona marinha ${ }^{15}$ ou espaço marinho, constituído pelo Mar Territorial ${ }^{16}$, pela Zona Contígua ${ }^{17}$, pela Zona Econômica Exclusiva $(\mathrm{ZEE})^{18}$ e pela Plataforma Continental ${ }^{19}$ compreende atualmente 3,5 milhões de $\mathrm{km}^{2}$, podendo atingir 4,5 milhões de $\mathrm{km}^{2}$ com a extensão da Plataforma Continental. O mar territorial constitui bem da União, de acordo com o artigo 20, inciso VI da Constituição Federal, enquanto apenas os recursos naturais da plataforma continental e da zona econômica exclusiva são bens da União, de acordo com o inciso $\mathrm{V}$ do mesmo dispositivo constitucional.

A existência de normas, de planos e de programas de gestão para cada espaço específico gera inseguran-

15 BRASIL. Ministério do Meio Ambiente. Zona Costeira e Marinha. Disponível em: <http://www.mma.gov.br/biodiversidade/biodiversidade-aquatica/zona-costeira-e-marinha>. Acesso em: 15 out. 2014.

16 Doze milhas marítimas, medidas a partir da linha de baixa-mar do litoral continental e insular. BRASIL. Lei no 8.617 de 04 de janeiro de 1993. Disponível em: <http://www.planalto.gov.br/ccivil_03/leis/ 18617.htm>. Acesso em: 05 out. 2014. Art. 1.

17 A zona contígua é uma faixa que se estende entre doze e vinte e quatro milhas, nela o Brasil possui competências para realizar medidas fiscalizatórias para evitar e reprimir infrações no seu território ou no seu mar territorial (BRASIL. Lei $n^{\circ} 8.617$ de 04 de janeiro de 1993. Disponível em: <http://www.planalto.gov.br/ccivil_03/leis/ 18617.htm>. Acesso em: 05 out. 2014. Art. $4^{\circ}$ e $5^{\circ}$ ).

$18 \mathrm{Na}$ zona econômica exclusiva — que compreende uma faixa estendida entre doze e duzentas milhas marítimas, contadas a partir da linha de base — o Brasil não possui soberania plena, mas somente para "fins de exploração, aproveitamento, conservação e gestão dos recursos naturais vivos e não vivos, das águas sobrejacentes ao leito do mar, do leito do mar e seu subsolo, e no que se refere a outras atividades com vistas à exploração e ao aproveitamento da zona para fins econômicos". Nessa região, a regulamentação da proteção e da preservação do meio marítimo; da construção, operação e uso de todos os tipos de ilhas artificiais, instalações e estruturas só pode ser realizada pelo Brasil; porém, a liberdade de navegação e sobrevoo e os demais usos do mar internacionalmente lícitos são permitidos aos demais Estados. O Brasil exerce soberania para fins de exploração dos recursos naturais vivos e não vivos e pode regulamentar de maneira exclusiva sobre a investigação científica marinha, a proteção e preservação do meio marinho, a construção, operação e o uso de todos os tipos de ilhas artificiais, instalações e estruturas (BRASIL. Lei $n^{\circ} 8.617$ de 04 de janeiro de 1993. Disponível em: <http://www. planalto.gov.br/ccivil_03/leis/18617.htm>. Acesso em: 05 out. 2014. art. $\left.6^{\circ}-10\right)$.

19 A plataforma continental compreende: o leito e o subsolo das áreas submarinas que se estendem além do seu mar territorial, em toda a extensão do prolongamento natural de seu território terrestre, até o bordo exterior da margem continental, ou até uma distância de duzentas milhas marítimas das linhas de base, a partir das quais se mede a largura do mar territorial, nos casos em que o bordo exterior da margem continental não atinja essa distância (BRASIL. Lei n ${ }^{\circ}$ 8.617 de 04 de janeiro de 1993. Disponível em: <http:/ / www.planalto. gov.br/ccivil_03/leis/18617.htm>. Acesso em: 05 out. 2014. Art. 11-13). ça jurídica, pois há pluralidade de normas, muitas vezes contraditórias, aplicáveis a áreas similares. Ao mesmo tempo, há outros temas que deveriam ser tratados de modo conjunto, como a interface entre as bacias hidrográficas ou o planejamento urbano e a zona costeira, mas ainda há limites para essas conexões. Para analisar se a delimitação desses espaços como costeiro, litorâneo e marítimo tem contribuído ou não para a segurança jurídica das atividades na região, é fundamental selecionar uma atividade como foco de estudo. Nesse caso, a construção civil constitui uma das atividades que pode ocorrer tanto na faixa terrestre quanto na faixa marítima da zona costeira, podendo ser potencialmente causadora de dano ao meio ambiente. Portanto, trata-se de tema que possibilita boa análise das incoerências normativas e institucionais no Brasil para a gestão sustentável dessa área.

O artigo irá se concentrar nas construções imobiliárias nas faixas terreste e marítima da zona costeira. As ocupações atreladas às atividades portuária e petrolífera não serão abordadas neste trabalho, pois a regulação desta normativa é específica e seus problemas jurídicos são diferentes. A gestão dos resíduos, da qualidade da água e da relação entre as bacias hidrográficas e a zona costeira também não serão objeto do presente artigo.

Considerando-se esse cenário, verifica-se a existência de limites institucionais (I) e normativos (II) em relação à gestão sustentável da ocupação da zona costeira. No caso do Brasil, não se trata de ausência, mas de pluralidade de instrumentos aplicáveis a essa região, mas que não são suficientemente precisos e claros para garantir a segurança jurídica nessa região.

\section{Os LiMites INSTITUCIONAIS}

Os limites institucionais para a gestão sustentável da zona costeira são perceptíveis na faixa terrestre e na faixa marítima. No primeiro caso, os limites mais evidentes relacionam-se às competências das entidades da federação para a proteção do meio ambiente. Em relação à faixa marítima, a gestão do planejamento costeiro é limitada, pois essas atribuições são concentradas na Autoridade Marítima (AM), cujas competências estão ligadas, sobretudo, às atividades de navegação. É relevante apresentar, primeiramente, a organização federativa brasileira no que concerne à proteção ambiental e à 
gestão da zona costeira para facilitar a compreensão dos limites institucionais.

A Constituição Federal estabelece, em seu artigo 225, que o meio ambiente ecologicamente equilibrado, de modo geral, é bem de uso comum das presentes e futuras gerações. No entanto, há reconhecimento expresso de alguns biomas que merecem proteção especial no art. $225, \sqrt{ } 4^{\circ}$, entre eles consta a Zona Costeira. O texto prevê que: "a Floresta Amazônica brasileira, a Mata Atlântica, a Serra do Mar, o Pantanal Mato-Grossense e a Zona Costeira são patrimônio nacional, e sua utilização far-se-á, na forma da lei". ${ }^{20}$ Resta compreender qual é o significado do reconhecimento da Zona Costeira como patrimônio nacional, para além do sentido meramente retórico, e qual é a distinção entre bem do patrimônio nacional e bem de uso comum do povo.

A competência legislativa relativa à elaboração de planos nacionais ou regionais de ordenação do território é da União. ${ }^{21}$ Destarte, à primeira vista, questões sobre o gerenciamento costeiro, cujo impacto dificilmente se limita ao âmbito local, alcançando proporções regionais ou nacionais, são do interesse do Instituto Brasileiro do Meio Ambiente e dos Recursos Naturais Renováveis (IBAMA), autarquia federal executora do Sistema $\mathrm{Na}$ cional do Meio Ambiente. ${ }^{22}$

Em relação às atividades de cunho administrativo na zona costeira, tem-se que, além do IBAMA, a faixa marítima da zona costeira é gerenciada pela Autoridade

20 BRASIL. Constituição (1988). Constituição da República Federativa do Brasil. Disponível em: < http://www.planalto.gov.br/ccivil_03/constituicao/constituicao.htm>. Acesso em: 05 ago. 2014.

21 Cf.: Art. 21. Compete à União: IX - elaborar e executar planos nacionais e regionais de ordenação do território e de desenvolvimento econômico e social; Art. 23. É competência comum da União, dos Estados, do Distrito Federal e dos Municípios: VI - proteger o meio ambiente e combater a poluição em qualquer de suas formas; VII preservar as florestas, a fauna e a flora; Art. 24. Compete à União, aos Estados e ao Distrito Federal legislar concorrentemente sobre: VI - florestas, caça, pesca, fauna, conservação da natureza, defesa do solo e dos recursos naturais, proteção do meio ambiente e controle da poluição; VIII - responsabilidade por dano ao meio ambiente, ao consumidor, a bens e direitos de valor artístico, estético, histórico, turístico e paisagístico. BRASIL. Constituição (1988). Constituição da República Federativa do Brasil. Disponível em: <http://www.planalto.gov.br/ccivil_03/constituicao/constituicao.htm>. Acesso em: 05 ago. 2014.

22 BRASIL. Constituição (1988). Constituição da República Federativa do Brasil. Disponível em: <http://www.planalto.gov.br/ccivil_03/constituicao/constituicao.htm>. Acesso em: 05 ago. 2014. BRASIL. Lei 6.938 de 31 de agosto de 1981. Disponível em: < http:/ / www.planalto.gov.br/ccivil_03/leis/16938.htm>. Acesso em: 4 out. 2014. Art. $6^{\circ}$, IV.
Marítima no que tange às construções realizadas nessa área, tendo como objetivo principal preservar a segurança da atividade de navegação ${ }^{23}$. A competência da AM deve ser anvaliada de modo crítico, tendo vem vista a necessidade da gestão integrada da zona costeira com outras atividades realizadas na área como a pesca e a proteção da biodiversidade marinha.

Nesse ínterim, é pertinente verificar os problemas relacionados à identificação do órgão de proteção ambiental competente para autorizar a ocupação sustentável da zona costeira (A); para, em seguida, apresentar os problemas da gestão integrada da zona costeira ligados à competência da AM para autorizar construções na área marítima (B).

A) A identificação do órgão de proteção ambiental competente para autorizar a ocupação sustentável da zona costeira

A identificação do órgão de proteção ambiental competente para autorizar a ocupação sustentável da zona costeira constitui um dos limites institucionais da gestão da zona costeira em relação à construção civil. Observa-se que a competência comum entre União, Estados e Municípios resulta em alguns conflitos no que tange ao órgão competente para o licenciamento ambiental de atividades na zona costeira. É relevante demonstrar que a causa desse conflito era a pouca clareza na delimitação da competência de cada ente federativo, o que foi parcialmente esclarecido pela Lei Complementar n. ${ }^{\circ} 140$ de 08 de dezembro de 2011, principalmente pela utilização aleatória de critérios para definir a competência de cada ente.

Antes da edição da Lei Complementar 140/2011, que cria regras para a cooperação nos processos de licenciamento ambiental, entre a União, os Estados, o Distrito Federal e os Municípios, havia interpretações diversas quanto ao ente competente para realizar o licenciamento ambiental de empreendimentos localizados na zona costeira. Os tribunais utilizavam alguns critérios, dispostos no art. 10 da Lei 6.938/81 (alterado pela norma supramencionada), como o interesse preponderante, a dimensão do impacto e a localização da unidade de conservação para determinar se um órgão estadual ou a União deveria ser competente para o licenciamento. No entanto, esses critérios eram deveras

23 BRASIL. Lei $n^{\circ} 9.966$ de 28 de abril de 2000. Disponível em: <http://www.planalto.gov.br/ccivil_03/leis/L9966.htm>. Acesso em: 4 out. 2014. Art. $2^{\circ}$, inciso XXII. 
abstratos e davam margem à subjetividade do órgão administrativo e judicial no momento de licenciar ou julgar licenças expedidas. Ademais, em diversos momentos, a norma supracitada mencionava ser competência supletiva do ente federal a concessão do licenciamento ambiental, porém não havia critérios objetivos que norteassem as hipóteses em que a competência supletiva devesse ser utilizada. De fato, em casos extremos, como quando a autoridade estadual omitia-se, restava claro identificar que o IBAMA deveria suprir a ausência estadual. No entanto, a jurisprudência analisada dos 5 Tribunais Regionais Federais nacionais demonstra que a quase unanimidade dos magistrados utilizava a competência supletiva como regra e não como exceção.

A esse respeito, cita-se o julgado abaixo, proveniente do TRF1, cuja controvérsia tratava de prédio que seria construído em região de dunas, já existindo licenciamento ambiental concedido pelo órgão estadual. O caso ilustra a confusão realizada nos tribunais em utilizar o argumento da proteção constitucional ao meio ambiente ecologicamente equilibrado como fundamento para requerer a atuação supletiva do IBAMA como regra:

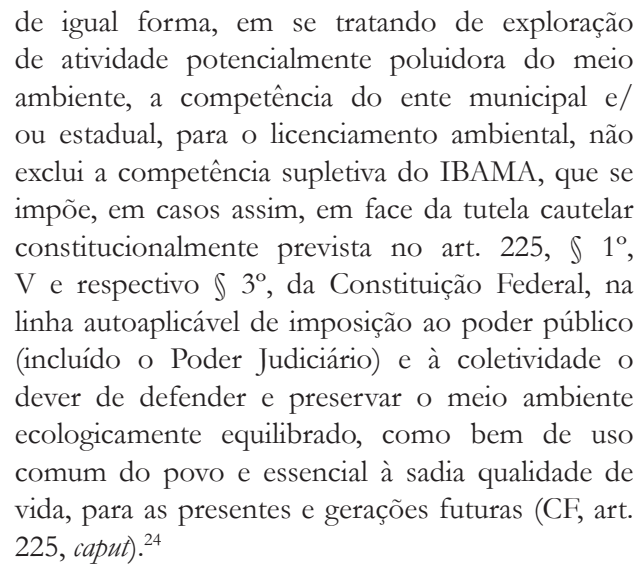

24 BRASIL. Tribunal Regional Federal da Primeira Região. Agravo de Instrumento. AG 183530620124010000 MA 0018353 06.2012.4.01.0000. Quinta Turma. Agravante: Delman Rodrigues Incorporações Ltda. Agravado: Ministério Público Federal. Relator: Des. Souza Prudente. Brasília, 31 de setembro de 2013. Disponível em: <http://trf-1.jusbrasil.com.br/jurisprudencia/24138498/ agravo-de-instrumento-ag-183530620124010000-ma0018353-0620124010000-trf1>. Acesso em: 5 ago. 2015. De forma similar, cf. BRASIL. Tribunal Regional Federal da Segunda Região. Apelação Cível. AC 200651080008781. Sexta Turma Especializada. Apelante: Denival da Silva Ferraz e outros. Apelado União Federal, Município de Araruama; IBAMA. Relator (a): Des. Federal Carmen Silvia Lima de Arruda. Rio de Janeiro, 31 de março de 2014. Disponível em: <http://trf-2.jusbrasil.com.br/jurisprudencia/25091049/ac-apelacao-civel-ac-200651080008781-trf2/ inteiro-teor-120459970>. Acesso em: 5 ago. 2015, nesse caso, para defender a necessidade da atuação do ente federal, a juíza afirmou
Rememore-se, também, que a lei 6.938 data de período anterior à atual Carta Magna, motivo pelo qual ela não contemplava a atuação municipal na proteção do meio ambiente. Com o advento da Constituição de 1988 e a autonomia que esta direcionou aos Municípios, impelia à criação de novo instrumento que permitisse a eles, entes mais próximos das populações afetadas pelo gerenciamento costeiro, maior ingerência sobre a política de zoneamento urbano e de licenciamento ambiental. ${ }^{25}$ Nesse contexto, a Lei Complementar (LC) n. ${ }^{\circ}$ 140/2011 logrou êxito em estabelecer expressamente a unicidade do órgão licenciador, bem como dispor sobre as hipóteses de atuação supletiva e de atuação subsidiária dos entes federativos, contribuindo para suprir a lacuna apontada acima ${ }^{26}$.

que toda a zona costeira é uma propriedade da União, ou seja, tanto a parte terrestre quanto a parte marítima da zona costeira nacional — que contém algumas municipalidades — seriam propriedade da União); BRASIL. Tribunal Regional Federal da Segunda Região. Agravo de Instrumento. AG 2012.02.01.004859-3. Quinta Turma Especializada. Agravante: IBAMA. Agravado: Thiago Cunha de Almeida. Relator: Des. Federal Marcus Abraham. Rio de Janeiro, 29 de janeiro de 2013. Disponível em: <http://trf-2.jusbrasil. com.br/jurisprudencia/23376162/ag-agravo-de-instrumento-ag201202010048593-trf2/inteiro-teor-111700881>. Acesso em: 5 ago. 2015; BRASIL. Tribunal Regional Federal da Segunda Região. Agravo de Instrumento. AG 2012.02.01.005724-7. Quinta Turma Especializada. Agravante: Ministério Publico Federal. Agravado: Aluísio Leal Santos. Relator: Des. Federal. Marcus Abraham. Rio de Janeiro, 28 de maio de 2013. Disponível em: < http://trf-2.jusbrasil.com.br/jurisprudencia/23610800/ag-agravo-de-instrumento-ag201202010057247-trf2/inteiro-teor-111757639>. Acesso em: 5 ago. 2015.

25 BRASIL. Lei $n^{\circ}$ 6.938, de 31 de agosto de 1981. Disponível em: $<$ http://www.planalto.gov.br/ccivil_03/leis/16938.htm>. Acesso em: 4 out. 2014. Art. 10; GUERRA, Sérgio. Licenciamento Ambiental de Acordo com a LC 140/2011. Revista de Direito Ambiental, São Paulo, v. 17, n. 66, p. 153-179, abr./jun. 2012. p. 155.

26 Art. 14. $\int 3^{\circ}$ O decurso dos prazos de licenciamento, sem a emissão da licença ambiental, não implica emissão tácita nem autoriza a prática de ato que dela dependa ou decorra, mas instaura a competência supletiva referida no art. 15. Art. 15. Os entes federativos devem atuar em caráter supletivo nas ações administrativas de licenciamento e na autorização ambiental, nas seguintes hipóteses: I - inexistindo órgão ambiental capacitado ou conselho de meio ambiente no Estado ou no Distrito Federal, a União deve desempenhar as ações administrativas estaduais ou distritais até a sua criação; II - inexistindo órgão ambiental capacitado ou conselho de meio ambiente no Município, o Estado deve desempenhar as ações administrativas municipais até a sua criação; e III - inexistindo órgão ambiental capacitado ou conselho de meio ambiente no Estado e no Município, a União deve desempenhar as ações administrativas até a sua criação em um daqueles entes federativos. Art. 16. A ação administrativa subsidiária dos entes federativos dar-se-á por meio de apoio técnico, científico, administrativo ou financeiro, sem prejuízo de outras formas de cooperação. Parágrafo único. A ação subsidiária deve ser solicitada pelo ente originariamente detentor da atribuição nos termos 
Especificamente em relação à divisão das competências para realizar o licencimento ambiental para a construção em região costeira, a LC 140 dispõe no art. $7^{\circ}$ parágrafo único ${ }^{27}$ que a União tem competência para promover o licenciamento: de empreendimentos e atividades localizados ou desenvolvidos no mar territorial, na plataforma continental ou na zona econômica exclusiva; em unidades de conservação instituídas pela União, exceto em Áreas de Proteção Ambiental (APAs) em dois ou mais Estados.

$\mathrm{O}$ art. $9^{\circ}$, inciso XIV elenca expressamente as competências dos Municípios em relação à concessão do licenciamento ambiental. $\mathrm{O}$ art. $8^{\circ}$, por sua vez, prevê que é competência dos Estados:

\begin{abstract}
XIV - promover o licenciamento ambiental de atividades ou empreendimentos utilizadores de recursos ambientais, efetiva ou potencialmente poluidores ou capazes, sob qualquer forma, de causar degradação ambiental, ressalvado o disposto nos arts. $7^{\circ}$ e $9^{\circ}$;

Art. $9^{\circ}$ São ações administrativas dos Municípios:
\end{abstract}

XIV - observadas as atribuições dos demais entes federativos previstas nesta Lei Complementar, promover o licenciamento ambiental das atividades ou empreendimentos:

a) que causem ou possam causar impacto ambiental de âmbito local, conforme tipologia definida pelos respectivos Conselhos Estaduais de Meio Ambiente, considerados os critérios de porte, potencial poluidor e natureza da atividade. ${ }^{28}$

Constata-se que a lei buscou compatibilizar os critérios já utilizados da autoridade instituidora e da abrangência do possível dano com as inovações de dotar os Estados de competência residual e da criação de Comissão Tripartite Nacional, órgão de caráter técnico, responsável pela proposição de tipologia de atividades com

desta Lei Complementar (BRASIL. Lei Complementar $n^{\circ} 140$, de 08 de dezembro de 2011. Disponível em: <http://www.planalto.gov.br/ ccivil_03/leis/lcp/Lcp140.htm>. Acesso em: 10 nov.2014).

27 Art. $7^{\circ}$, parágrafo único. O licenciamento dos empreendimentos cuja localização compreenda concomitantemente áreas das faixas terrestre e marítima da zona costeira será de atribuição da União exclusivamente nos casos previstos em tipologia estabelecida por ato do Poder Executivo, a partir de proposição da Comissão Tripartite Nacional, assegurada a participação de um membro do Conselho Nacional do Meio Ambiente (CONAMA) e considerados os critérios de porte, potencial poluidor e natureza da atividade ou empreendimento. BRASIL. Lei Complementar $n^{\circ} 140$, de 08 de dezembro de 2011. Disponível em: <http://www.planalto.gov.br/ccivil_03/ leis/lcp/Lcp140.htm>. Acesso em: 10 nov.2014

28 BRASIL. Lei Complementar n 140, de 08 de dezembro de 2011. Disponível em: <http://www.planalto.gov.br/ccivil_03/leis/lcp/ Lcp140.htm>. Acesso em: 10 nov.2014. maior risco de degradação ao meio ambiente.

Ressalta-se, ainda, a disposição contida no art. 13, caput e parágrafos $1^{\circ}$ e $2^{\circ}$ que possibilita a manifestação não vinculativa dos demais entes federativos ao órgão responsável pela licença ou autorização. Avalia-se que esse dispositivo buscou concatenar o principio da proteção integral ao meio ambiente com a unicidade do órgão licenciador. Isso porque, conforme já relatado acima, em diversos casos estudados, ainda sob o auspício da legislação anterior, construções que possuíam licença concedida por órgão municipal ou estadual, algumas delas já sendo desenvolvidas há anos, tiveram que ser suspensas em razão da manifestação de interesse do IBAMA na lide e, na quase totalidade deles, o judiciário acabava vinculando-se ao posicionamento do ente federal, utilizando argumentos confusos e, por vezes, incoerentes. A título de exemplo, apresenta-se o julgado abaixo que versa sobre uma ação civil pública que buscava a reparação de dano ambiental ocasionado em razão da construção de um muro de contenção e edificação sobre costão rochoso da Ilha Grande. Esta está inserida na Área de Proteção Ambiental de Tamoios, unidade de conservação instituída pelo Estado do Rio de Janeiro. Nesse caso o magistrado atribui a competência do IBAMA para realizar o licenciamento ambiental pelo mero fato de a construção se inserir em área de zona costeira, sem demonstrar se existiria algum impacto de âmbito regional ou nacional:

[...] nesse quadrante, a despeito de a construção empreendida pelo Demandado se situar na Área de Proteção Ambiental de Tamoios - unidade de conservação criada pelo Estado do Rio de Janeiro (Decreto $\mathrm{n}^{\circ}$ 9.452/86) e administrada pelo INEA (Instituto Estadual do Ambiente/RJ) -, o interesse nacional na lide está claramente delineado nos argumentos expendidos na inicial da ação coletiva, que apontam a ocorrência de edificação irregular, sem prévio licenciamento ambiental, ocasionando degradação ambiental em virtude da alteração das características naturais de região localizada em Zona Costeira, considerada constitucionalmente patrimônio nacional (art. 225, $\left.₫ 4^{\circ}, \mathrm{CF}\right)^{29}$.

29 BRASIL. Tribunal Regional Federal da Segunda Região. Agravo de Instrumento. AG 2012.02.01.004859-3. Quinta Turma Especializada. Agravante: IBAMA. Agravado: Thiago Cunha de Almeida. Relator: Des. Federal Marcus Abraham. Rio de Janeiro, 29 de janeiro de 2013. Disponível em: <http://trf-2.jusbrasil. com.br/jurisprudencia/23376162/ag-agravo-de-instrumento-ag201202010048593-trf2/inteiro-teor-111700881>. Acesso em: 5 ago. 2015. Contrariando esse entendimento, e verificando a adequação do particular às regras estaduais de proteção ao meio ambiente, a despeito do manifesto interesse do IBAMA: "Entendo que o em- 
Diante desses casos, não se questiona o fato de que a intervenção do IBAMA no processo de licenciamento tenha proporcionado maior lisura e proteção ao meio ambiente, isso porque os entes estaduais e municipais, por vezes, não possuem capacidade técnica e recursos suficientes para exercer suas atividades de forma satisfatória. Argumenta-se que essa incapacidade estrutural, que não possuía respaldo normativo, não poderia ser utilizada genericamente a ponto de suprimir as competências dos órgãos estadual e municipal, visando suprir por meio judicial insuficiências administrativas.

Mesmo em decisões em que se busca argumentos mais precisos para se justificar a intervenção do IBAMA em razão da configuração do interesse nacional da área, argumentos ligados ao patrimônio nacional ainda são utilizados. Não se questiona o resultado da decisão, mas sim os argumentos que são utilizados para sustentá-la. Por exemplo, pode ser citado um caso de empreendimento localizado em Área de Preservação Permanente como o mangue, com proteção específica na Lei $n^{\circ}$ 4.771/65. Nessa circunstância, há julgados no sentido de que o IBAMA seria o órgão competente não apenas pela omissão do órgão estadual competente, mas pelo fato de que a Zona Costeira seria patrimônio nacional, como pode ser verificado abaixo:

2. a ação civil pública originária foi ajuizada pelo
Parquet Federal, que busca o reconhecimento da
competência do IBAMA para o licenciamento
ambiental de empreendimento sito, segundo
afirma, na Zona Costeira (Loteamento Jardim
Fortaleza), com exigência de apresentação de
estudo de impacto ambiental e relatório de impacto
do meio ambiente. 3. Segundo vistoria realizada

preendimento compatibilizou o uso e a sustentabilidade do meio. A área urbana será ocupada, porém com baixa densidade ocupacional, acompanhada de projetos de manutenção e andou na esteira das declarações periciais, está de acordo com a legislação vigente, sendo a área costeira, o terreno de marinha e a restinga legal e legitimamente respeitados, associados a um empreendimento urbano devidamente licenciado pelos órgãos municipal e estadual, como é de direito conforme seu tamanho (inferior a $100 \mathrm{ha}$ e destinado a ocupação de cerca de 400 pessoas), nos termos de toda a legislação supratranscrita. Não procede, então, a pretensão original do Ministério Público Federal de vedar qualquer empreendimento no local. Ante o exposto, voto por negar provimento aos recursos de apelação da União, do Ministério Público Federal e do IBAMA, para julgar improcedente esta Ação Civil Pública” (BRASIL. Tribunal Federal da Quarta Região. Recurso Especial em Apelação Cível. $A C n^{o}$ 0000959-87.2009.404.7216/SC. Terceira Turma. Recorrente: IBAMA. Recorrido: Territorial Garopaba Ltda. Relator(a): Des. Maria Lúcia Luz Leiria. Porto Alegre, 19 de agosto de 2012. Disponível em: <http://www.jusbrasil.com.br/diarios/64854576/trf-4-judicial-17-01-2014-pg-75>. Acesso em: 5 ago. 2015. pelo órgão ambiental, a área do loteamento está encravada em borda de manguezal, em bacia de inundação do Rio Cocó, sofrendo a influência das marés e em campo de duna. [...] Constatouse, em procedimento administrativo, em tais áreas, o desmonte de dunas fixas, o desmatamento e a abertura de vias de acesso e terraplanagem, tudo sem licenciamento ambiental. 5. In casu, como a área do loteamento está inserta em borda de manguezal, em bacia de inundação do Rio Cocó, sofrendo a influência das marés, ou seja, como se trata de área de interação entre mar e terra, então, tem-se que se está diante de área integrante de Zona Costeira. Em função dessa localização, considerando-se que se trata de área patrimonial nacional, por expressa dicção do Texto Constitucional, evidencia-se a competência do IBAMA para o licenciamento ambiental de empreendimentos que pretendam nela de estabelecer, ações humanas essas que não poderão prescindir de EIA e de RIMA. ${ }^{30}$

Verifica-se que há insegurança jurídica na identificação clara de qual órgão deve ser competente para o licenciamento ambiental de empreendimentos na zona costeira. Por um lado, o poder municipal está normalmente mais próximo do empreendimento e do empresário e, além disso, possui competência para realizar o zoneamento urbano. Dessa forma, esse ente teria melhores condições de avaliar a possível extensão do dano de uma construção e de identificar a boa-fé e a capacidade técnica do empresário para realizar o em-

30 BRASIL. Tribunal Regional Federal da Quinta Região. Agravo de Instrumento. AGTR 107968/CE - 0009668-67.2010.4.05.0000. Primeira Turma. Agravante: Ministério Público Federal. Agravado: Construtora Waldyr Diogo Ltda e outros. Relator : Des. Federal Francisco Cavalcanti. Recife, 03 de maio de 2012. Disponível em: $<$ http://www.jusbrasil.com.br/diarios/37330603/trf-5-jud-25-052012-pg-57>. Acesso em: 5 ago. 2015. Num sentido similar cf.: BRASIL. Tribunal Federal da Quarta Região. Apelação Cível. AC 500022869.2010.404.7216/SC. Vice-Presidência. Apelante: Orlando Ivã larionoff. Apelado: IBAMA. Relator: Des. Federal Luiz Fernando Wowk Pentead. Porto Alegre, 02 de outubro de 2014. Disponível em: $<$ http://trf-4.jusbrasil.com.br/jurisprudencia/143419040/apelacao-civel-ac-50002286920104047216-sc-5000228-6920104047216/ inteiro-teor-143419116>. Acesso em: 5 ago. 2015; BRASIL. Tribunal Federal da Quarta Região. Recurso Especial em Apelação Cível. AC 0000959-87.2009.404.7216/SC. Terceira Turma. Recorrente: IBAMA. Recorrido: Territorial Garopaba Ltda. Relator(a): Des. Maria Lúcia Luz Leiria. Porto Alegre, 19 de agosto de 2012. Disponível em: <http://www.jusbrasil.com.br/diarios/64854576/trf-4-judicial-17-01-2014-pg-75>. Acesso em: 5 ago. 2015; BRASIL. Tribunal Regional Federal da Quarta Região. Apelação Cível. AC 0004571 88.2003.404.7201/SC. Terceira Turma. Apelante IBAMA; Ministério Público Federal. Apelado: Município de Itapoá/SC. Relator (a): Des. Federal Maria Lúcia Luz Leiria. Porto Alegre, 1 de fevereiro de 2011. Disponível em: <http://trf-4.jusbrasil.com.br/jurisprudencia/18575379/apelacao-civel-ac-7201-sc-0004571-8820034047201trf4/inteiro-teor-18575380>. Acesso em: 5 ago. 2015. 
preendimento $^{31}$. Por outro lado, o órgão federal possui, teoricamente, maior capacidade técnica e orçamentária para avaliar riscos, além de conceber estudos de impacto em níveis regionais ou nacionais e não estar restrito à região local. Antes da Lei Complementar n. 140, muitos julgados interpretaram no sentido de que toda construção na zona costeira tem impacto nacional em razão de sua condição de patrimônio nacional, o que resultou na indicação da competência do IBAMA para o licenciamento da atividade, embora o PNGC seja expresso ao afirmar que o critério para a concessão da licença deve ser o da extensão do dano ${ }^{32}$. Caberá, nesse momento, aguardar a aplicação dos dispositivos de coordenação existentes da LC n. ${ }^{\circ} 140$ a fim de verificar se haverá maior precisão dos critérios que serão utilizados para determinar a competência da União, do Estado ou do Município para licenciar esses empreendimentos, haja vista que, nenhum dos julgados encontrados nos endereços eletrônicos dos Tribunais Regionais Federais nacionais já tenha aplicado a citada lei.

Além desse limite institucional, identifica-se a existência de questões prejudiciais à gestão sustentável e integrada da zona costeira decorrentes da competência da Autoridade Marítima para autorizar as construções nessa área.

B) Os problemas de gestão integrada da zona costeira ligados à competência da Autoridade Marítima para autorizar as construções nessa região

Os problemas ligados à competência da Autoridade Marítima (AM) para autorizar construções na região costeira estão relacionados, entre outros motivos, à prioridade dada à navegação. Os usos múltiplos da zona costeira não são coordenados de forma a propiciar que o planejamento da zona costeira pudesse ser dividido de forma equânime ou razoável entre os órgãos competentes. Diversos órgãos federais e estaduais também têm suas respectivas competências relacionadas à gestão da zona costeira, como o Ministério da Pesca e o IBAMA, ou os órgãos estatais responsáveis por elaborar o

31 Cf.: Art. 30. Compete aos Municípios: VIII - promover, no que couber, adequado ordenamento territorial, mediante planejamento e controle do uso, do parcelamento e da ocupação do solo urbano. BRASIL. Constituição (1988). Constituição da República Federativa do Brasil. Disponível em: <http://www.planalto.gov.br/ccivil_03/ constituicao/constituicao.htm>. Acesso em: 05 ago. 2014.

32 BRASIL. Decreto no 5.300, de 07 de dezembro de 2004. Disponível em: <http://www.planalto.gov.br/ccivil_03/_ato2004-2006/2004/ decreto/D5300.htm>. Acesso em: 10 jul. 2014.
Zoneamento Ecológico-Econômico da zona costeira, o que intensifica a complexidade da gestão integrada dessa região. É pertinente avaliar os limites da AM para conduzir a uma gestão integrada da zona costeira em razão, por exemplo, da centralidade que a atividade de navegação desempenha entre as competências da AM e da ausência de coordenação de sua atuação com a de outros órgãos federais e/ou estaduais.

A AM, nos termos do Regimento da Comissão Interministerial para os Recursos do Mar (CIRM) ${ }^{33}$, tem a competência para exercer a coordenação das atividades desta $^{34}$. Ela aprecia, entre outras competências, "O planejamento de atividades relacionadas com os recursos do mar, propondo ao Presidente da República prioridades para os programas e projetos que o integram" ${ }^{35}$. A lei que dispõe sobre a prevenção, o controle e a fiscalização da poluição causada por lançamento de óleo e outras substâncias nocivas ou perigosas em águas sob jurisdição nacional prevê no art. $2^{\circ}$ inciso XXII que

Autoridade Marítima é a autoridade exercida
diretamente pelo Comandante da Marinha,
responsável pela salvaguarda da vida humana e
segurança da navegação no mar aberto e hidrovias
interiores, bem como pela prevenção da poluição
ambiental causada por navios, plataformas e suas
instalações de apoio [...]" ${ }^{36}$

Nota-se que as atribuições da AM abarcam o planejamento de todas as atividades marinhas, mas a sua competência principal está conectada à atividade de navegação.

Apesar da Política Nacional para os Recursos do Mar (PNRM) ${ }^{37}$ orientar no sentido do desenvolvimento coordenado das atividades no mar territorial, na ZEE e na

33 BRASIL. Comissão Interministerial para os Recursos do Mar. Resolução no 01, de 21 de novembro de 1990. Disponível em: < https://www.mar.mil.br/secirm/document/ataseresolucoes/resolucao-1-1994.pdf>. Acesso em: 05 ago. 2015.

34 BRASIL. Comissão Interministerial para os Recursos do Mar. Resolução no 01, de 21 de novembro de 1990. Disponível em: < https://www.mar.mil.br/secirm/document/ataseresolucoes/resolucao-1-1994.pdf>. Acesso em: 05 ago. 2015.

35 BRASIL. Comissão Interministerial para os Recursos do Mar. Resolução no 01, de 21 de novembro de 1990. Disponível em: < https://www.mar.mil.br/secirm/document/ataseresolucoes/resolucao-1-1994.pdf>. Acesso em: 05 ago. 2015, artigo 5º inciso II.

36 BRASIL. Lei $n^{0} 9.966$ de 28 de abril de 2000. Disponível em: $<$ http://www.planalto.gov.br/ccivil_03/leis/L9966.htm>. Acesso em: 4 out. 2014.

37 BRASIL. Decreto $n^{0} .5 .377$ de 23 de fevereiro de 2005. Disponível em: <http://www.planalto.gov.br/ccivil_03/_Ato20042006/2005/Decreto/D5377.htm>. Acesso em: 06 ago. 2015. 
plataforma continental ${ }^{38}$, a navegação não está integrada entre as atividades que devem ser objeto dessa gestão integrada. $\mathrm{O}$ art. $3^{\circ}$ da PNRM prevê quais são os recursos vivos e não vivos marinhos que devem ser objeto de gestão integrada dos ambientes costeiro e oceânico ${ }^{39}$, quais sejam: os recursos pesqueiros, a diversidade biológica, os minerais, os recursos energéticos, a aquicultura, as atividades turísticas. Contudo, a lei exclui expressamente o transporte marítimo de cargas ${ }^{40}$. Portanto, embora a CIRM seja a instituição competente para coordenar a consecução da PNRM, nos termos do artigo $8^{\circ}$ da Política, há separação entre a atividade de navegação e as demais.

Há uma norma específica que estabelece os procedimentos para a realização de obras sob, sobre e às margens das águas jurisdicionais brasileiras ${ }^{41}$. A Marinha do Brasil tem a competência de avaliar a execução de obras nessa área e de emitir pareceres quanto ao "ordenamento do espaço aquaviário e à segurança da navegação, sem prejuízo das obrigações do interessado perante os demais órgãos responsáveis pelo controle da atividade em questão" "42. O Diretor de Portos e Costas (DPC) é o representante da Autoridade Marítima para a Segurança do Tráfego Aquaviário e tem, entre outras competências, "determinar a elaboração de normas da Autoridade Marítima relativas à execução de obras, dragagens, pesquisa e lavra de minerais sob, sobre e às margens das águas sob jurisdição nacional". As Capitanias (CP), Delegacias (DL) e Agências (AG) devem ser consultadas antes do início da execução das obras públicas localizadas na área em questão ${ }^{43}$.

38 BRASIL. Decreto $n^{0} .5 .377$ de 23 de fevereiro de 2005. Disponível em: <http://www.planalto.gov.br/ccivil_03/_Ato2004-2006/2005/ Decreto/D5377.htm>. Acesso em: 06 ago. 2015, artigo $2^{\circ}$.

39 BRASIL. Decreto $n^{0} .5 .377$ de 23 de fevereiro de 2005. Disponível em: <http://www.planalto.gov.br/ccivil_03/_Ato20042006/2005/Decreto/D5377.htm>. Acesso em: 06 ago. 2015Acesso em: out. 2014, artigo $7^{\circ}$.

40 BRASIL. Decreto $n^{0} .5 .377$ de 23 de fevereiro de 2005. Disponível em: <http://www.planalto.gov.br/ccivil_03/_Ato20042006/2005/Decreto/D5377.htm>. Acesso em: 06 ago. 2015, artigo 3.

41 BRASIL. Marinha do Brasil. Normas da autoridade marítima para obras, dragagens, pesquisa e lavra de minerais sob, sobre e às margens das águas jurisdicionais brasileiras: NORMAM 11/DPC. 2003. Disponível em: <https://www3.dpc.mar.mil.br/normam/N_11/normam11.pdf $>$. Acesso em: 05 ago. 2015.

42 BRASIL. Marinha do Brasil. Normas da autoridade marítima para obras, dragagens, pesquisa e lavra de minerais sob, sobre e às margens das águas jurisdicionais brasileiras: NORMAM 11/DPC. 2003. Disponível em: <https://www3.dpc.mar.mil.br/normam/N_11/normam11.pdf>. Acesso em: 05 ago. 2015. Capítulo 1, 0102, a) - Competência.

43 BRASIL. Marinha do Brasil. Normas da autoridade marítima para
As atividades que estão sob a competência da Autoridade Marítima, representada pelos seus diversos órgãos, são: obras em geral ${ }^{44}$; portos ou instalações portuárias, cais, píeres, molhes, trapiches, marinas ou similares ${ }^{45}$ que podem ou não ser precedidas de aterro que requer documentos adicionais que comprovem que não haverá danos à navegação; viveiros para aquicultura ${ }^{46}$, com uma breve indicação das competências do Ministério da Pesca nesse contexto; autorização para lançamento de petrechos para atração e/ou captura de pescado ${ }^{47}$; lançamento de cabos e dutos submarinos ou estruturas similares ${ }^{48}$; construção de pontes rodoviárias ou similares sobre águas ${ }^{49}$; plataformas e unidades de produção de petróleo ou gás ${ }^{50}$; flutuantes ou outras embarcações fundeadas não destinadas à navegação ${ }^{51}$. A AM não pre-

obras, dragagens, pesquisa e lavra de minerais sob, sobre e às margens das águas jurisdicionais brasileiras: NORMAM 11/DPC. 2003. Disponível em: $<$ https://www3.dpc.mar.mil.br/normam/N_11/normam11.pdf>. Acesso em: 05 ago. 2015. Capítulo 1, 0103.

44 BRASIL. Marinha do Brasil. Normas da autoridade marítima para obras, dragagens, pesquisa e lavra de minerais sob, sobre e às margens das águas jurisdicionais brasileiras: NORMAM 11/DPC. 2003. Disponível em: <https://www3.dpc.mar.mil.br/normam/N_11/normam11.pdf>. Acesso em: 05 ago. 2015. 0106.

45 BRASIL. Marinha do Brasil. Normas da autoridade marítima para obras, dragagens, pesquisa e lavra de minerais sob, sobre e às margens das águas jurisdicionais brasileiras: NORMAM 11/DPC. 2003. Disponível em: <https://www3.dpc.mar.mil.br/normam/N_11/normam11.pdf>. Acesso em: 05 ago. 2015. 0107.

46 BRASIL. Marinha do Brasil. Normas da autoridade marítima para obras, dragagens, pesquisa e lavra de minerais sob, sobre e às margens das águas jurisdicionais brasileiras: NORMAM 11/DPC. 2003. Disponível em: <https://www3.dpc.mar.mil.br/normam/N_11/normam11.pdf>. Acesso em: 05 ago. 2015. 0108.

47 BRASIL. Marinha do Brasil. Normas da autoridade marítima para obras, dragagens, pesquisa e lavra de minerais sob, sobre e às margens das águas jurisdicionais brasileiras: NORMAM 11/DPC. 2003. Disponível em: $<$ https://www3.dpc.mar.mil.br/normam/N_11/normam11.pdf $>$. Acesso em: 05 ago. 2015. 0109.

48 BRASIL. Marinha do Brasil. Normas da autoridade marítima para obras, dragagens, pesquisa e lavra de minerais sob, sobre e às margens das águas jurisdicionais brasileiras: NORMAM 11/DPC. 2003. Disponível em: $<$ https://www3.dpc.mar.mil.br/normam/N_11/normam11.pdf $>$. Acesso em: 05 ago. 2015. 0110.

49 BRASIL. Marinha do Brasil. Normas da autoridade maritima para obras, dragagens, pesquisa e lavra de minerais sob, sobre e às margens das águas jurisdicionais brasileiras: NORMAM 11/DPC. 2003. Disponível em: <https://www3.dpc.mar.mil.br/normam/N_11/normam11.pdf>. Acesso em: 05 ago. 2015. 0111.

50 BRASIL. Marinha do Brasil. Normas da autoridade marítima para obras, dragagens, pesquisa e lavra de minerais sob, sobre e às margens das águas jurisdicionais brasileiras: NORMAM 11/DPC. 2003. Disponível em: $<$ https://www3.dpc.mar.mil.br/normam/N_11/normam11.pdf $>$. Acesso em: 05 ago. 2015. 0113.

51 BRASIL. Marinha do Brasil. Normas da autoridade marítima para obras, dragagens, pesquisa e lavra de minerais sob, sobre e às margens das águas jurisdicionais brasileiras: NORMAM 
cisa emitir o seu parecer em casos de requerimentos de obras em rios não navegáveis. Diante dessas competências estabelecidas, nota-se uma preocupação central da atuação da AM nas atividades que possam gerar insegurança à navegação.

A despeito da competência central conectada à navegação, a Norman 11 prevê a necessidade de coordenação entre a AM, o Ministério da Pesca e órgãos ambientais. No entanto, os instrumentos previstos para essa coordenação são limitados, pois prepondera a centralidade da navegação diante de outras atividades. Por exemplo, a Norman prevê que o Ministério da Pesca deve encaminhar consulta à CP com jurisdição sobre a área onde se pretende realizar o projeto para que seja dado um parecer. Após manifestação contrária ou favorável à atividade da $\mathrm{CP}$, o processo é encaminhado ao DN para a apreciação dos aspectos de sua competência. A apreciação dos órgãos da Marinha está diretamente conectada à análise dos prejuízos que podem ser causados à navegação, de acordo com o seguinte artigo da Norman 11:

[...] nos espaços físicos intermediários entre áreas aquícolas ou seus conjuntos, circunscritos aos limites dos parques aquícolas, não será gerada nenhuma restrição de acesso e de tráfego, ou outra, devendo essa circunstância ser enunciada no projeto de delimitação dos parques e área aquícolas e ratificada no parecer do Representante da Autoridade Marítima. Caso haja necessidade de restrição a quaisquer atividades que venham afetar a segurança da navegação, a salvaguarda da vida humana no mar, a prevenção da poluição por embarcação e o ordenamento do tráfego aquaviário, deverá haver previsão no projeto específico encaminhado pelo MPA a anuência expressa no parecer conclusivo emitido pelo Representante da Autoridade Marítima [...]. Em situações especiais, onde houver comprometimento total da segurança da navegação e da preservação da normalidade do tráfego aquaviário, a princípio, não será emitido parecer favorável às instalações de criatórios, viveiros ou equipamentos similares utilizados na aquicultura. ${ }^{52}$

A Norman 11 faz menção à necessidade de coordenação das atividades nessa área com o Zoneamento Ecológico-Econômico e com o respectivo Plano de

11/DPC. 2003. Disponível em: <https://www3.dpc.mar.mil.br/ normam/N_11/normam11.pdf>. Acesso em: 05 ago. 2015, 0114.

52 BRASIL. Marinha do Brasil. Normas da autoridade marítima para obras, dragagens, pesquisa e lavra de minerais sob, sobre e às margens das águas jurisdicionais brasileiras: NORMAM 11/DPC. 2003. Disponível em: <https://www3.dpc.mar.mil.br/ normam/N_11/normam11.pdf>. Acesso em: 05 ago. 2015.
Gestão Costeira dos Planos de Gerenciamento Costeiro Estadual e Municipal. Entretanto, não há previsão específica de como essa coordenação ocorrerá a fim de promover a gestão integrada dos usos múltiplos da zona $\operatorname{costeira}^{53}$. É relevante apontar que há poucos Estados que tenham instituído o zoneamento estadual, instrumento central na gestão integrada das atividades, com destaque para os zoneamentos de São Paulo e do Ceará ${ }^{54}$. Ademais, muitos Estados também não elaboraram os seus Planos de Gerenciamento Costeiro Estadual ${ }^{55}$ ou normas relacionadas à pesca ${ }^{56}$, o que compartilha a

53 Entre os pontos destacados no VII Plano Setorial para os Recursos do Mar, aprovado pelo Decreto $\mathrm{n}^{\circ}$ 6.678, de 08 de dezembro de 2008, D.O.U de 09/12/2008, está a "A mitigação dos danos causados pela erosão costeira demandará estudos para a identificação, o dimensionamento e o impacto ambiental para viabilizar o uso dos granulados na reconstituição de perfis de praia". BRASIL. Decreto $n^{\circ}$ 6.678, de 8 de dezembro de 2008. Disponível em: <http:// www.planalto.gov.br/ccivil_03/_Ato2007-2010/2008/Decreto/ D6678.htm > . Acesso em: 05 ago. 2015. Ver sobre o tema: RUFINO, Gilberto d'Avila. Patrimônio costeiro e seus fundamentos jurídicos. In: MORAES, Antônio Carlos Robert; ZAMBONI, Adenilson (Org.). Subsídios para um projeto de gestão. Brasília: MMA, 2004. (Projeto Orla).

54 Sobre o tema, ver: SODRÉ, Marcelo Gomes. Zoneamento Ecológico-econômico e zoneamento costeiro: algumas polêmicas jurídicas In: GRANZIERA, Maria Luiza Machado; GONÇALVES, Alcindo (Org.). Os problemas da zona costeira no Brasil e no mundo. Santos: Universitária Leopoldianum, 2012. p. 116-141. p. 120.

55 Leis estaduais sobre o tema de zonas costeiras: SÃO PAULO. Lei $n^{\circ} 10.019$ de 3 de julbo de 1998. Dispõe sobre o Plano Estadual de Gerenciamento Costeiro e dá outras providências. Disponível em: <http://www.al.sp.gov.br/repositorio/legislacao/lei/1998/lei10019-03.07.1998.html>. Acesso em: 05 ago. 2015; CEARÁ. Lei no 13.796, de 30 de junho de 2006. Institui a Política Estadual de Gerenciamento Costeiro, e o Plano Estadual de Gerenciamento Costeiro e dá outras providências. Disponível em: <http:/ /www.al.ce.gov.br/ legislativo/legislacao5/leis2006/13796.htm>. Acesso em: 05 ago. 2015; ESPÍRITO SANTO. Lei ñ 5.816, de 22 de dezembro de 1998. Institui o Plano Estadual de Gerenciamento Costeiro do Espírito Santo. Disponível em: < http://www.meioambiente.es.gov.br/web/ Lei_5816.htm>. Acesso em: 05 ago. 2015. ver: RUFINO, Gilberto d'Ávila. Royalties do petróleo e diretos dos Municípios produtores: elementos para análise e discussão. Disponível em: <www.ijlitoral.org >. Acesso em: 05 nov. 2012; RUFINO, RUFINO, Gilberto d'Ávila. Royalties do petróleo para Municípios costeiros. Disponível em: <www.ijlitoral.org>. Acesso em: 11 nov. 2012.

56 Exemplos de normas estaduais sobre a pesca: SÃO PAULO. Lei $n^{\circ} 11.165$, de 27 de junho de 2002. Institui o Código de Pesca e Aqüicultura do Estado. Disponível em: < http://www.al.sp.gov.br/ repositorio/legislacao/lei/2002/lei-11165-27.06.2002.html>. Acesso em: 05 ago. 2015; RIO GRANDE DO SUL. Lei $n^{\circ} 11.886$, de 2 de janeiro de 2003. Dá nova redação ao artigo $1^{\circ}$. da Lei Estadual n. 8.676, de 14 de julho de 1988, que determina a obrigatoriedade de demarcação das áreas de pesca, lazer ou recreação, nos Municípios com orla marítima, lacustre e fluvial Disponível em: $<$ http://www. legislacao.sefaz.rs.gov.br/Site/Document.aspx?inpKey=102719\&in pCodDispositive $=\&$ inpDsKeywords=> . Acesso em: 05 ago. 2015; RIO DE JANEIRO. Lei no 2.423, de 17 de agosto de 1995. Disci- 
responsabilidade pelas lacunas identificadas na gestão costeira. Há, também, procedimentos que a prefeitura municipal deve intervir juntamente com a Autoridade Marítima $^{57}$.

Um projeto de lei de 2013 tenta modificar a lógica da gestão do meio ambiente costeiro, sobretudo da faixa marítima, criando o Bioma marinho ${ }^{58}$. Essa mudança poderia resultar na gestão integrada da zona costeira e da zona oceânica, tendo como objeto central de tutela o bioma e não as atividades desenvolvidas nessa área. O que se observa hoje constitui a gestão costeira da faixa marinha centralizada na navegação. Todavia, trata-se apenas de projeto de lei que ainda está em tramitação, podendo levar anos para sua aprovação ou sofrer emendas que desnaturem a sua estrutura atual.

A gestão integrada depende não apenas da atividade dos órgãos federais, como a Autoridade Marítima, mas também dos órgãos estaduais e municipais que detêm competências constitucionais ligadas às atividades realizadas na zona costeira que envolvam interesses regional ou local ${ }^{59}$. A gestão deve ter como base as peculiaridades do meio ambiente marinho e das atividades desenvolvidas na área, sem concentração específica em uma das atividades.

Além das insuficiências institucionais apontadas, existem limites normativos que dificultam a gestão integrada da zona costeira brasileira, alguns deles serão destacados a seguir.

\section{Os LIMITES NORMATIVOS}

No Brasil, a normatização da zona costeira ocorreu de forma desordenada e mais centralizada na peculiari-

plina a pesca nos cursos d'água do Estado do Rio de Janeiro e adota outras providências. Disponível em: < http://gov-rj.jusbrasil.com. br/legislacao/150735/lei-2423-95>. Acesso em: 05 ago. 2015.

57 BRASIL. Ministério de Minas e Energia. Departamento Nacional de Produção Mineral. Portaria n 441, de 11 de dezembro de 2009. Disponível em: <http://www2.dnpm.gov.br/conteudo.asp?IDSe $\mathrm{cao}=67 \&$ IDPagina $=84 \&$ IDLegislacao $=589>$. Acesso em: 5 ago. 2015.

58 BRASIL. Camara dos Deputados. Projeto de lei 6969 de 17 de dezembro de 2013. Disponível em: <http://www.camara.gov.br/ proposicoesWeb/fichadetramitacao?idProposicao $=604557>$. Acesso em: 5 ago. 2015.

59 FREITAS, Vladimir Passos de; FREITAS, Dario Almeida Passos de. A proteção do meio ambiente na zona costeira. In: GRANZIERA, Maria Luiza Machado; GONÇALVES, Alcindo (Org.). Os problemas da zona costeira no Brasil e no mundo. Santos: Universitária Leopoldianum, 2012. p. 257-277. p. 260. dade de cada atividade desenvolvida nessa área do que na gestão sustentável dos usos múltiplos da zona costeira. Há quantidade expressiva de normas, por vezes contraditórias, aplicáveis a um mesmo espaço. Os limites decorrentes desse fenômeno podem ser constatados tanto pela possibilidade de ocupação desordenada da zona costeira em razão da utilização imprecisa de conceitos (A) como pela necessidade de restrição geral à construção no litoral (B).

A) A possibilidade de ocupação desordenada da zona costeira em razão da utilização imprecisa de conceitos

A possibilidade de ocupação desordenada da zona costeira tem como uma de suas causas a utilização imprecisa, pelos tribunais nacionais, dos seguintes termos: "bem de uso comum do povo"; "bens da União" e "patrimônio nacional”. Em alguns casos, não é realizada nenhuma diferenciação entre os termos que acabam sendo empregados como sinônimos. Em outros, a aplicação legislativa acaba sendo correta, porém, por causa da utilização de argumentos confusos e pouco precisos, as decisões abrem margem à interposição de recursos, $\mathrm{O}$ que resulta em um prolongamento da ação judicial por um período imcompatível com a lógica de preservação da zona costeira. Dessa forma, a maior precisão com relação ao regime jurídico aplicável à zona costeira pode permitir maior segurança jurídica às pessoas públicas e privadas que gerem e que ocupem a região. Para tanto, é fundamental definir os três termos supracitados, demonstrar a utilização imprecisa dos conceitos nas decisões e identificar em que medida esse emprego ambíguo contribui para a ocupação desordenada da zona costeira.

Com relação ao termo patrimônio nacional, o $₫ 4^{\circ}$ do art. 225 da Constituição Federal seleciona alguns biomas nacionais que, por serem essenciais à preservação da biodiversidade, necessitam de proteção diferenciada. Desse modo, o citado dispositivo determina que: "a Floresta Amazônica brasileira, a Mata Atlântica, a Serra do Mar, o Pantanal Mato-Grossense e a Zona Costeira são patrimônio nacional, e sua utilização far-se-á, na forma da lei, dentro de condições que assegurem a preservação do meio ambiente, inclusive quanto ao uso dos recursos naturais" ${ }^{\prime 0}$. Mas, qual seria o quadro jurí-

60 Cf.: BRASIL. Constituição (1988). Constituição da República Federativa do Brasil. Disponível em: <http://www.planalto.gov.br/ ccivil_03/constituicao/constituicao.htm>. Acesso em: 05 ago. 2014. 
dico aplicável a um bem elevado ao status de patrimônio nacional?

Entende-se que o status de patrimônio nacional é uma qualificação que se sobrepõe ao titulo de propriedade, atribuído a algumas áreas reconhecidamente relevantes para a manutenção dos Biomas nacionais para as gerações futuras. Porquanto, exige-se do possuidor, por meio de lei, a adoção de cuidados que assegurem a preservação dos recursos naturais ali existentes ${ }^{61}$. Não haveria qualquer relação direta com o pertencimento à União ou mesmo com a possibilidade de fruição indiscriminada da zona costeira por toda a coletividade.

Por outro lado, o caput do mesmo art. 225 dispõe que o meio ambiente ecologicamente equilibrado é bem de uso comum do povo que deve ser preservado para as gerações presentes e futuras. ${ }^{62}$ Os bens de uso comum do povo são caracterizados por pertencerem à coletividade, serem inalienáveis e não permitirem usucapião, não obstante possam ser utilizados mediante cobrança de valor. A legislação brasileira infraconstitucional indica como exemplos: os rios, mares, estradas, ruas, praças e a praia. ${ }^{63}$

Os bens da União, por sua vez, estão elencados no art. 20 da Constituição Federal. Entre eles, interessa para essa análise citar os seguintes:

\begin{abstract}
IV - as ilhas fluviais e lacustres nas zonas limítrofes com outros países; as praias marítimas; as ilhas oceânicas e as costeiras, excluídas, destas, as que contenham a sede de Municípios, exceto aquelas áreas afetadas ao serviço público e a unidade ambiental federal, e as referidas no art. 26, II;
\end{abstract}

61 Cf.: "Patrimônio Nacional - conjunto de bens pertencentes à Nação Brasileira, de uso comum, cujas características especiais, de valor histórico, paisagístico, sócio-econômico, ambiental ou outras características congêneres, lhe conferem "status" especial, exigindo a preservação de suas condições básicas de existência". BRASIL. Ministério do Meio Ambiente. Plano Nacional de Gerenciamento Costeiro (PNGC II). 1997. Disponível em: < http://www.mma. gov.br/images/arquivo/80033/0.PNGC-II97\%20Resolucao05_97. CIRM.pdf>. Acesso em: 15 out. 2014. SILVA, Solange Teles da. Direito fundamental ao meio ambiente ecologicamente equilibrado: avanços e desafios. Revista de Direito Ambiental, São Paulo, v. 12, n. 48, p. 225-245, out./dez. 2007. p. 233).

62 Cf.: BRASIL. Constituição (1988). Constituição da República Federativa do Brasil. Disponível em: <http://www.planalto.gov. br/ccivil_03/constituicao/constituicao.htm>. Acesso em: 05 ago. 2014).

63 BRASIL, Lei $n^{\circ} 10.406$, de 10 de janeiro de 2002. Disponível em: <http://www.planalto.gov.br/ccivil_03/leis/2002/110406.htm >. Acesso em: 05 ago. 2015. Artigo 99 e seguintes. BRASIL. Lei n 7.661 de 16 de maio de 1998. Disponível em: <http://www.planalto.gov.br/ ccivil_03/leis/17661.htm>. Acesso em: 04 ago. 2015. Artigo 10.
VI - o mar territorial;

VII - os terrenos de marinha e seus acrescidos;[...]

Dessa forma, tanto a praia, como o mar territorial e os terrenos da marinha estão contidos nas classificações de "bem de uso comum do povo" e "bem da União".

Sobre esse tema, o Decreto 5.300 define a zona costeira em seu artigo $3^{\circ}$ como região de interação entre mar, ar e terra, compreendendo uma faixa marítima de até 12 milhas náuticas e uma faixa terrestre que corresponde aos limites de determinados Municípios que sofrem influencia dos fenômenos ocorrentes na zona costeira. Posto isso, identifica-se que, em relação à faixa marítima, é pacífica sua natureza jurídica como bem da União por expressa previsão constitucional. Contudo, quanto à faixa terrestre, não há precisão com relação ao que pode ou não ser apropriado por particulares. Há interpretações, por exemplo, no sentido de que a classificação da zona costeira como patrimônio nacional não impede a sua apropriação por particulares. A designação como patrimônio nacional somente ressalta a necessidade de proteção específica da região em razão de sua importância ecossistêmica ${ }^{64}$.

A esse respeito, o STF se posicionou em sede de Recurso Extraordinário interposto pelo Estado de São Paulo contra decisão do Tribunal de Justiça do Estado de São Paulo que o condenou ao pagamento de indenização a particular que teve seu direito de propriedade limitado por meio da criação de uma Estação Ecológica. No caso, a Suprema Corte acenou positivamente quanto ao exercício dos direitos decorrentes da propriedade de área localizada em uma região integrante da zona costeira, dizendo que essa faixa não seria propriedade da União:

[...] o preceito consubstanciado no art. 225, par. $4^{\circ}$, da Carta da República, além de não haver convertido em bens públicos os imóveis particulares abrangidos pelas florestas e pelas matas nele referidas (Mata atlântica, Serra do Mar, Floresta Amazônica brasileira), também não impede a utilização, pelos próprios particulares, dos recursos naturais existentes naquelas áreas que estejam sujeitas ao domínio privado, desde que observadas as prescrições legais e respeitadas as condições necessárias à preservação ambiental ${ }^{65}$.

64 FREITAS, Vladimir Passos de; FREITAS, Dario Almeida Passos de. A proteção do meio ambiente na zona costeira. In: GRANZIERA, Maria Luiza Machado; GONÇALVES, Alcindo (Org.). Os problemas da zona costeira no Brasil e no mundo. Santos: Universitária Leopoldianum, 2012. p. 257-277. p. 258.

65 BRASIL. Supremo Tribunal Federal. Recurso Extraordinário. 
Uma forma de compatibilizar esse entendimento firmado pela Suprema Corte com a disposição prevista no caput do art. $225 \mathrm{da} \mathrm{CF}$, em relação à parte terrestre da zona costeira, seria mitigar as características do bem de uso comum do povo por meio de uma adequação aos planos de zoneamento territorial dos Municípios. Outra alternativa seria coincidir os limites terrestres da zona costeira às dimensões terrestres da orla marítima, descrita no art. 23, Decreto 5.300/2004. Embora essa previsão requeira mudança legislativa, seria de maior coerência, pois permitiria um gerenciamento mais intenso das áreas diretamente influenciadas pela faixa marítima, prevenindo a degradação provocada por grandes projetos imobiliários.

Foram encontradas algumas decisões em consonância com esse entendimento, a exemplo da seguinte, que versa sobre construção realizada em área de promontório, localizado na Mata Atlântica, em dimensões superiores às permitidas pelo licenciamento concedido pelo órgão ambiental estadual:

\begin{abstract}
[...] é em nome do interesse coletivo que insistimos na proteção da Mata Atlântica, como meio para salvaguardar a proteção da diversidade biológica, das nascentes, da qualidade e disponibilidade da água. Em larga escala, somados os impactos desta propriedade com a propriedade vizinha, e ainda a outra e mais aquela, as pequenas ações exploratórias particulares acabam produzindo uma grande e comunitária perda generalizada, duradoura e de difícil recuperação. Não se trata de radicalizar a dicotomia entre o público e o privado, espoliando o bem particular em nome de um suposto bem coletivo teórico que ignora a pessoa. E não se trata de decidir pela supremacia da individualidade ignorando o impacto social das intervenções. Esta é uma falsa dicotomia. ${ }^{66}$
\end{abstract}

RE 134297 SP. Primeira Turma. Recorrente: Estado de São Paulo. Recorridos: Paulo Ferreira Ramos e Cônjuge. Relator: Min. Celso de Mello. Brasília, 13 de junho de 1995. Disponível em<http://stf. jusbrasil.com.br/jurisprudencia/745994/recurso-extraordinario-re134297-sp>. Acesso em: 05 ago. 2015.

66 Ver BRASIL. Tribunal Federal da Quarta Região. Apelação Cível. AC 5000228-69.2010.404.7216/SC. Vice-Presidência. Apelante: Orlando Ivã larionoff. Apelado: IBAMA. Relator: Des. Federal Luiz Fernando Wowk Pentead. Porto Alegre, 02 de outubro de 2014. Disponível em: <http:// trf-4.jusbrasil.com.br/jurisprudencia/143419040/apelacao-civelac-50002286920104047216-sc-5000228-6920104047216/inteiroteor-143419116>. Acesso em: 5 ago. 2015. No mesmo sentido: BRASIL. Tribunal Federal da Quarta Região. Recurso Especial em Apelação Cível. AC no 0000959-87.2009.404.7216/SC. Terceira Turma. Recorrente: IBAMA. Recorrido: Territorial Garopaba Ltda. Relator(a): Des. Maria Lúcia Luz Leiria. Porto Alegre, 19 de agosto de 2012. Disponível em: <http://www.jusbrasil.com.br/ diarios/64854576/trf-4-judicial-17-01-2014-pg-75>. Acesso em: 5
Em contrapartida, verifica-se que essa posição não é perene e que ainda há tribunais que utilizam os conceitos de patrimônio nacional e de bem de uso comum do povo de forma imprecisa. Nesse sentido, segue o trecho abaixo da ementa de Agravo de Instrumento interposto pelo IBAMA contra decisão que reconhecia a competência estadual para julgar controvérsia relativa a construção realizada em costão rochoso localização em Área de Proteção Ambiental instituída pelo Estado do Rio de Janeiro. Nesse caso, já citado anteriormente neste artigo, o argumento utilizado pelo relator no seu voto, transcrito abaixo, não é claro em relação aos motivos que comprovaram que o interesse é de âmbito nacional:

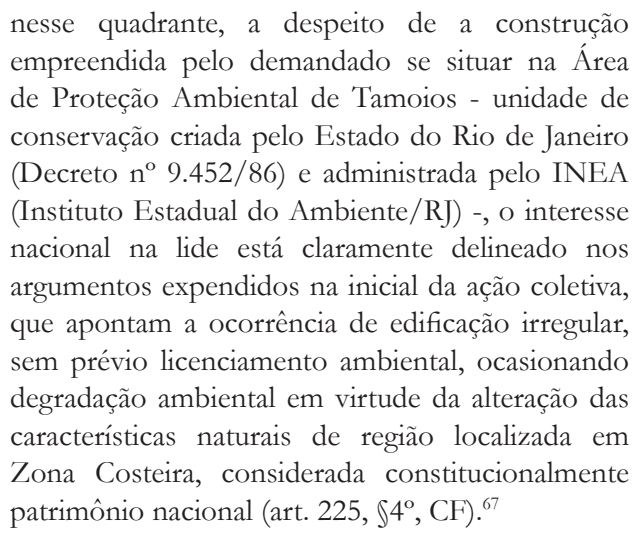

Ilustrativamente, cita-se também trecho do voto da relatora, que foi seguido pelos demais desembargadores, em Apelação Cível em que donos de quiosques construídos em região de restinga questionavam decisão da administração pública que determinava a retirada das construções. A magistrada incorreu em impropriedade ao afirmar que a zona costeira é bem público da União:

ago. 2015;. BRASIL. Tribunal Regional Federal da Quarta Região. Apelação Cível. AC 0004571-88.2003.404.7201/SC. Terceira Turma. Apelante IBAMA; Ministério Público Federal. Apelado: Município de Itapoá/SC. Relator (a): Des. Federal Maria Lúcia Luz Leiria. Porto Alegre, 1 de fevereiro de 2011. Disponível em: <http://trf-4. jusbrasil.com.br/jurisprudencia/18575379/apelacao-civel-ac-7201sc-0004571-8820034047201-trf4/inteiro-teor-18575380>. Acesso em: 5 ago. 2015;. BRASIL. Tribunal Regional Federal da Quinta Região. Agravo de Instrumento. AGTR 107968/CE - 000966867.2010.4.05.0000. Primeira Turma. Agravante: Ministério Público Federal. Agravado: Construtora Waldyr Diogo Ltda e outros. Relator: Des. Federal Francisco Cavalcanti. Recife, 03 de maio de 2012. Disponível em: <http://www.jusbrasil.com.br/diarios/37330603/ trf-5-jud-25-05-2012-pg-57>. Acesso em: 5 ago. 2015.

67 BRASIL. Tribunal Regional Federal da Segunda Região. Agravo de Instrumento. AG 2012.02.01.004859-3. Quinta Turma Especializada. Agravante: IBAMA. Agravado: Thiago Cunha de Almeida. Relator: Des. Federal Marcus Abraham. Rio de Janeiro, 29 de janeiro de 2013. Disponível em: <http://trf-2.jusbrasil.com.br/jurisprudencia/23376162/ag-agravo-de-instrumento-ag-201202010048593-trf2/ inteiro-teor-111700881>. Acesso em: 5 ago. 2015 
[...] não obstante as zonas costeiras serem bens públicos da União, é certo também que a Zona Costeira, nos termos do art. 225, $\int 4^{\circ}$, da $\mathrm{CF} / 88$, é, ao lado da Floresta Amazônica Brasileira, da Mata Atlântica, da Serra do Mar, do Pantanal MatoGrossense, uma área definida pela própria Carta Magna, diante da expressiva diversidade biológica destes biomas, como "patrimônio nacional", o que assinala que os regionalismos não devem se sobrepor aos interesses ambientais nacionais. Em outras palavras, ainda que exista sim um interesse estadual, distrital ou municipal, é certo que sempre existirá, nestes ecossistemas, um interesse de extensão em todo o território nacional. ${ }^{68}$

Portanto, conforme restou demonstrado, ainda há casos em que os conceitos de bem comum do povo, bem da União e patrimônio nacional são utilizados de forma indiscriminada e confusa, enfraquecendo a motivação das decisões judiciais, possibilitando interpretações diversas e dando margem à interposição de recursos. Esse fato reduz a proteção ambiental, tanto em âmbito administrativo, pois os órgãos gestores municipais, estaduais e federal não possuem parâmetros claros de atuação, quanto em âmbito judicial, já que cada órgão julgador desenvolve uma hermenêutica diferente sobre os institutos jurídicos.

Em relação à parte marítima da zona costeira, é relevante assinalar a necessidade de estipular uma restrição geral de construir na faixa litoral, que não existe no quadro normativo nacional e tem gerado efeitos positivos

68 BRASIL. Tribunal Regional Federal da Segunda Região. Apelação Cível. AC 200651080008781. Sexta Turma Especializada. Apelante: Denival da Silva Ferraz e outros. Apelado União Federal, Município de Araruama; IBAMA. Relator (a): Des. Federal Carmen Silvia Lima de Arruda. Rio de Janeiro, 31 de março de 2014. Disponível em: <http://trf-2.jusbrasil.com.br/jurisprudencia/25091049/acapelacao-civel-ac-200651080008781-trf2/inteiro-teor-120459970>. Acesso em: 5 ago. 2015 (nesse caso, a Juíza afirmou que toda a zona costeira faz parte dos bens da União, ou seja, tanto a parte marítima quanto a parte terrestre da zona costeira brasileira — que engloba a região de alguns Municípios — faria parte dos bens da União). De forma semelhante: BRASIL. Tribunal Regional Federal da Segunda Região. Agravo de Instrumento. AG 2012.02.01.004859-3. Quinta Turma Especializada. Agravante: IBAMA. Agravado: Thiago Cunha de Almeida. Relator: Des. Federal Marcus Abraham. Rio de Janeiro, 29 de janeiro de 2013. Disponível em: <http://trf-2. jusbrasil.com.br/jurisprudencia/23376162/ag-agravo-de-instrumento-ag-201202010048593-trf2/inteiro-teor-111700881>. Acesso em: 5 ago. 2015; BRASIL. Tribunal Regional Federal da Segunda Região. Agravo de Instrumento. AG 2012.02.01.005724-7. Quinta Turma Especializada. Agravante: Ministério Público Federal. Agravado: Aluísio Leal Santos. Relator: Des. Federal. Marcus Abraham. Rio de Janeiro, 28 de maio de 2013. Disponível em: < http://trf-2. jusbrasil.com.br/jurisprudencia/23610800/ag-agravo-de-instrumento-ag-201202010057247-trf2/inteiro-teor-111757639>. Acesso em: 5 ago. 2015. em países que adotaram essa política.

B) A necessidade de restrição geral de construir na zona costeira brasileira

No Brasil não há uma restrição geral de construir no litoral brasileiro. Essa omissão possibilita que cada Município preveja regras locais de ocupação da zona costeira. Algumas previsões legais contribuem à proteção geral dessa zona, como a propriedade pública dos terrenos de marinha ou a proteção ao meio ambiente, mas essa proteção não cobre uma dimensão específica. Nesse contexto, é essencial compreender os motivos da inexistência de proteção geral de uma faixa da zona costeira e a contribuição dos terrenos de marinha e das normas ambientais para limitar a atividade da construção civil na zona costeira.

O primeiro projeto legislativo do Plano Nacional para o Gerenciamento Costeiro, o Projeto n. ${ }^{\circ}$ 3.759/1984, previa uma distância específica de faixa litorânea de 12 milhas náuticas e de $12 \mathrm{~km}$ de largura na faixa terrestre. ${ }^{69}$ Essa medida não foi adotada no projeto seguinte, o Projeto 216-A/1987, que resultou na Lei n. ${ }^{\circ}$ 7.661/1988. Na França, por exemplo, o artigo L. 146-4III do código de urbanismo prevê 100 metros de faixa litorânea onde não é possível construir. ${ }^{70}$ Outros países preveem uma faixa litorânea de proteção da zona costeira de mais de 50 metros $^{71}$. No Brasil não há uma lei geral que possa interditar a construção na faixa terrestre da zona costeira, pois a competência para o planejamento do espaço urbano pertence aos municípios.

Há Estados que possuem normas sobre esse assunto, como a Constituição do Estado da Paraíba, que prevê que os Municípios devem seguir alguns parâmetros específicos para construir na zona costeira. São eles: nas zonas já construídas, é obrigatório respeitar uma distân-

69 MACHADO, Paulo Affonso Leme. Direito ambiental brasileiro. 21. ed. São Paulo: Malheiros, 2012. p. 1070.

70 Artigo L146-4-III do Código de Urbanismo francês: "En dehors des espaces urbanisés, les constructions ou installations sont interdites sur une bande littorale de cent mètres à compter de la limite haute du rivage ou des plus hautes eaux pour les plans d'eau intérieurs". Sobre esse tema ver LOITZENBAUER, Ester; MENDES, Carlos André Bulhões. A faixa terrestre da zona costeira e os recursos hídricos na região hidrográfica do Atlântico Sul. Revista de Gestão Costeira Integrada, Lisboa, v. 14, n. 1, p. 81-94, mar. 2014. p. 349.

71 Sobre esse tema ver: NOIN Daniel. La population des littoraux du monde. L'information géographique, Paris, v. 63, n. 2, p. 65-73, 1999. Disponível em: <http://www.persee.fr/web/revues/home/prescript/article/ingeo_0020-0093_1999_num_63_2_2632>. Acesso em: 4 ago. 2015. 
cia de 12,90 metros, enquanto, para as zonas que não possuem construções, é necessário respeitar a distância de $150 \mathrm{~m}$ do litoral marítimo ${ }^{72}$. Porém, essa não é a realidade de todo o país.

Alguns instrumentos podem contribuir com a proteção da zona costeira. Nesse sentido, os terrenos de marinha - que existem desde o século XIX, quando o país ainda era colônia de Portugal — são um dos instrumentos mais interessantes no direito brasileiro. Trata-se de um mecanismo que garante a propriedade da União sobre o litoral.

Os terrenos de marinha estão previstos na CF como bem público, sob a propriedade a União ${ }^{73}$. O Decreto-lei n. ${ }^{\circ}$ 9.760/46 prevê, em seu artigo $2^{\circ}$, uma distância horizontal do terreno de marinha fixado a 33 metros em direção à parte terrestre, com base em uma linha específica $^{74}$ definida pelo órgão público competente pela gestão dos bens da União ${ }^{75}$. A importância dessa zona decorre de sua fixação como propriedade da União: por consequência, em relação a essa área, aplica-se e é exercido um regime jurídico que deve ser seguido pelas pessoas privadas que se encontram sob uma concessão. Assim, se o Estado decide utilizar essa região, ele não precisa indenizar aqueles aos quais tenha sido concedida a utilização dessa região. As pessoas privadas podem utilizar os terrenos de marinha, mas devem pagar retribuição à União. Ademais, esta pode conceder a utilização

72 MACHADO, Paulo Affonso Leme. Direito ambiental brasileiro. 21 ed. São Paulo: Malheiros, 2012, p. 1069.

73 BRASIL. Constituição (1988). Constituição da República Federativa do Brasil. Disponível em: < http://www.planalto.gov.br/ccivil_03/constituicao/constituicao.htm>. Acesso em: 05 ago. 2014, artigo 20, inciso VII.

74 BRASIL. Decreto-lei no 9.760, de 05 de setembro de 1946. Disponível em: <http://www.planalto.gov.br/ccivil_03/decreto-lei/del9760. htm>. Acesso em: 05 ago. 2015. BRASIL. Constituição (1988). Constituição da República Federativa do Brasil. Disponível em: <http:/ / www.planalto.gov.br/ccivil_03/constituicao/constituicao.htm>. Acesso em: 05 ago. 2014artigo 20, inciso VII.

75 Secretaria do Patrimônio da União (SPU). Alguns casos postulando a mudança dessa linha já foram submetidos aos tribunais nacionais, pois os proprietários não estão de acordo que essa linha seja medida de modo unilateral pela administração pública. Ver sobre o tema: BRASIL. Tribunal Regional Federal da Quarta Região. Acordão. Processo 1998.7204.003633-7. Terceira Turma. Relator: Des. Federal Fernando Quadros. Porto Alegre, 30 de novembro de 2010; BRASIL. Supremo Tribunal Federal. Medida Cautelar na Ação Direta de Inconstitucionalidade. ADI 4264 MC/PE. Tribunal Pleno. Requerente: Assembléia Legislativa do Estado de Pernambuco. Requerido: Presidente da República. Relator: Min. Ricardo Lewandowski. Brasília, 16 de março de 2011. Disponivel em: <http://redir.stf.jus.br/ paginadorpub $/$ paginador.jsp?doc $\mathrm{TP}=\mathrm{AC} \& \operatorname{doc} \mathrm{ID}=623508>$. Acesso em: 05 ago. 2015. dessa área a particulares que ofereçam serviço público, como os serviços portuários ${ }^{76}$. A obrigação de pagar uma taxa de ocupação está prevista no Decreto-Lei e a sua legalidade foi confirmada em muitas decisões judiciais $^{77}$. Atualmente, existem projetos de Emenda Constitucional e de revisão legislativa que tentam extinguir os terrenos de marinha; até o momento, esses projetos não põem fim ao regime dos terrenos de marinha ${ }^{78}$. Alguns deles baseiam-se no argumento de que esse bem deve ser privatizado, pois seu pertencimento à esfera públi-

76 A reserva de território para o uso portuário segundo o Programa Geral de Autorizações da Agência Nacional de Transportes em vias navegáveis (ANTAQ). Ver sobre o tema: AGENCIA NACIONAL DE TRANSPORTES AQUAVIARIOS. PGO Plano Geral de Outorgas: apresentações. Disponível em : <http://www.antaq.gov. br/portal/Portos_PGO.asp>. Acesso em 10 set. 2014.

77 BRASIL. Tribunal Regional Federal da Segunda Região. Apelação/Reexame Necessário. APELRE 200851020028899 RJ. Sexta Turma Especializada. Apelante: União Federal. Apelado: Leonardo Almendra Honorato e Outros. Relator (a). Des. Federal: Carmen Silvia Lima Arruda. Rio de Janeiro, de 2014. Disponível em: <http://trf-2.jusbrasil.com.br/jurisprudencia/160029380/ apelacao-reexame-necessario-apelre-200851020028899-rj/inteiroteor-160029517>. Acesso em: 06 ago. 2015; BRASIL. Superior Tribunal de Justiça. Recurso Especial. Resp. $n^{\circ}$ 1183546/ES. Segunda Turma. Recorrente: S/A A Gazeta e Outros. Recorrido: União. Relator: Min. Mauro Campbel Marques. Brasília, 08 setembro de 2010. Disponível em: <http://stj.jusbrasil.com.br/jurisprudencia/16376533/recurso-especial-resp-1183546-es-2010-0040958-3/ relatorio-e-voto-16978062>. Acesso em: 05 ago. 2015.

78 Por exemplo: BRASIL. Câmara dos deputados. Projeto de Emenda Constitucional $n^{\circ}$ 603, de 1998. Disponível em: <http://www2. camara.leg.br/atividade-legislativa/comissoes/comissoes-temporarias/especiais/52a-legislatura/pec-603-98-terrenos-de-marinha $>$. Acesso em 06 ago. 2015; BRASIL. Câmara dos deputados. Projeto de Emenda Constitucional $n^{\circ}$ 53, de 2007. Disponível em: <http:// www.camara.gov.br/proposicoesWeb/fichadetramitacao?idPropo sicao $=349704>$. Acesso em 06 ago. 2015; BRASIL. Senado Federal. Projeto de Emenda Constitucional $n^{\circ} 56$, de 2009. Disponível em: $<$ http://www.senado.leg.br/atividade/materia/detalhes.asp?p_ cod_mate $=95166>$. Acesso em 06 ago. 2015; BRASIL. Câmara dos deputados. Projeto de Emenda Constitucional n ${ }^{\circ} 39$, de 2011. Disponível em: <http://www.camara.gov.br/proposicoesWeb/fichadetramitac ao?idProposicao=508965>. Acesso em 06 ago. 2015; BRASIL. Câmara dos deputados. Projeto de lei $n^{\circ}$ 6623, de 2006. Disponível em: $<$ http://www.camara.gov.br/proposicoesWeb/fichadetramitacao ?idProposicao=313821>. Acesso em 06 ago. 2015; BRASIL. Câmara dos deputados. Projeto de lei $n^{\circ}$ 6752, de 2010. Disponível em: $<$ http://www.camara.gov.br/proposicoesWeb/fichadetramitacao ?idProposicao=465829>. Acesso em 06 ago. 2015; BRASIL. Câmara dos deputados. Projeto de lei $n^{0}$ 1082, de 2011. Disponível em: $<$ http://www.camara.gov.br/proposicoesWeb/fichadetramitacao?i dProposicao=498619>. Acesso em 06 ago. 2015; BRASIL. Senado Federal. Projeto de Emenda Constitucional $n^{\circ}$ 256, de 2011. Disponível em: <http://www.senado.gov.br/atividade/materia/detalhes. asp?p_cod_mate $=100239>$. Acesso em 06 ago. 2015; BRASIL. Câmara dos deputados. Projeto de lei $n^{0} 1117$, de 2011. Disponível em: <http://www.camara.gov.br/proposicoesWeb/fichadetramitacao?i dProposicao=498959> . Acesso em 06 ago. 2015. 
ca deu-se em um contexto de necessidade de segurança na zona costeira durante a colonização - situação inexistente atualmente. Outros projetos sustentam que os terrenos de marinha deveriam ser considerados como propriedade dos Municípios ou dos Estados e não da União $^{79}$. Os proprietários de terrenos ligados a essas regiões argumentam que já pagam os impostos atinentes à propriedade e que não devem pagar também o foro, taxa relacionada com a ocupação de terrenos públicos ${ }^{80}$.

Defende-se que, de forma contrária ao acima descrito, os projetos deveriam ter feito proposições para aumentar as funções dos terrenos de marinha. Por exemplo, eles poderiam ter sugerido a integração da função de proteção ao meio ambiente ou de planejamento urbano de forma a contribuir com o planejamento da zona costeira, o que não foi feito ${ }^{81}$. Portanto, seria interessante que os terrenos de marinha fossem definidos de forma mais abrangente concedendo-lhes atribuições mais amplas do que sua atual função de proteção da navegação e da segurança da zona costeira. Destaca-se o fato de que os terrenos de marinha fazem parte da zona costeira e, por esse motivo, também são considerados patrimônio nacional ${ }^{82}$. Por esse motivo, essa área não deve ser protegida somente por leis federais, mas igualmente pelas normas locais, como o Plano Diretor da Cidade.

A zona costeira pode ser protegida ainda pelas normas ambientais ${ }^{83}$ e por dispositivos sobre o urbanismo.

79 BRASIL. Senado Federal. Projeto de Emenda Constitucional n ${ }^{\circ}$ 256, de 2011. Disponível em: <http://www.senado.gov.br/atividade/materia/detalhes.asp?p_cod_mate $=100239>$. Acesso em 06 ago. 2015; BRASIL. Câmara dos deputados. Projeto de Emenda Constitucional $n^{\circ}$ 39, de 2011. Disponível em: <http://www.camara.gov.br/proposicoesWeb $/$ fichadetramitacao?idProposicao $=508965>$. Acesso em 06 ago. 2015.

80 BRASIL. Câmara dos deputados. Projeto de lei ñ 6752, de 2010. Disponível em: <http://www.camara.gov.br/proposicoesWeb/fic hadetramitacao?idProposicao=465829> . Acesso em 06 ago. 2015.

81 Para um estudo dos projetos ver: ARZABE, Jorge. Gestão da zona costeira e os terrenos de marinha. 2011. $60 \mathrm{f}$. Trabalho de Conclusão de Curso (Especialista) - Curso Intensivo de Pós-Graduação em Administração Pública, Programa FGV Management, Fundação Getúlio Vargas, Brasília, 2011. p. 31.

82 Sobre o tema ver: RUFINO, Gilberto d'Avila. Patrimônio costeiro e seus fundamentos jurídicos. In: MORAES, Antônio Carlos Robert; ZAMBONI, Adenilson (Org.). Subsídios para um projeto de gestão. Brasília: MMA, 2004. (Projeto Orla). p. 65 e ss.

83 ALMEIDA, José Mauro de Lima O. de. Terrenos de marinha, proteção ambiental e as cidades. Belém: Paka-Tatu, 2008. p. 54. DE FREITAS, Vladimir Passos. FREITAS, Vladimir Passos de; FREITAS, Dario Almeida Passos de. A proteção do meio ambiente na zona costeira. In: GRANZIERA, Maria Luiza Machado; GONÇALVES,
De maneira geral, os terrenos de marinha não são considerados como áreas de proteção permanente ou unidades de conservação. Em contrapartida, como há áreas protegidas localizadas na zona costeira, esse território pode ser protegido por normas ambientais. Um caso interessante que ilustra essa possibilidade de proteção ocorreu na Ação Civil Pública, proposta pelo Ministério Público para a demolição de alguns prédios que tinham sido construídos numa área de proteção permanente. O juiz confirmou que as construções não poderiam ter sido realizadas nas áreas de proteção de Saco do Cais, de Paraty-Mirim — situado na cidade de Paraty —, porque se tratava de Área de Proteção Permanente conhecida como Cairuçu e, consequentemente, faltava a autorização do órgão ambiental competente para a construção civil. A decisão afirma que "[...] essa atitude causou prejuízos ao meio ambiente, pois, em razão da construção desses edifícios, houve uma mudança das características naturais da zona costeira" ${ }^{\prime 4}$. Ademais, é interessante apontar que alguns tribunais, em matéria ambiental, já se declararam competentes para julgar ações relacionadas a terrenos de marinha ${ }^{85}$.

Alcindo (Org.). Os problemas da zona costeira no Brasil e no mundo. Santos: Universitária Leopoldianum, 2012. p. 257-277.

84 “"...] esse ato causou danos ao meio ambiente, uma vez que, em decorrência das construções, não obstante estivessem embargadas, foram alteradas as características naturais da zona costeira", BRASIL. Tribunal Regional Federal da Segunda Região. Ação Cível. AC n. ${ }^{\circ}$ 487271. Sexta Turma especializada. Rio de Janeiro, em 19 de março de 2012. No mesmo sentido ver: BRASIL. Tribunal Regional Federal da Segunda Região. Ação Cível. AC 585795. Sétima turma especializada. Rio de Janeiro, 30 de outubro de 2013; ADI 4264 MC/PE. Tribunal Pleno. Requerente: Assembléia Legislativa do Estado de Pernambuco. Requerido: Presidente da República. Relator: Min. Ricardo Lewandowski. Brasília, 16 de março de 2011. Disponivel em: <http://redir.stf.jus.br/paginadorpub/paginador. jsp?docTP=AC\&docID=623508 $>$. Acesso em: 05 ago. 2015 ; BRASIL. Tribunal Regional Federal da Primeira Região. Apelação Cível. AC 350 BA 1998.33.01.000350-0. Sexta Turma. Apelante: Golden Beach Hotel Ltda. Apelado: União Federal. Relator(a): Des. Federal Maria Isabel Gallotti Rodrigues. Brasília, 31 de maio de 2014. Disponível em: <http://trf-1.jusbrasil.com.br/jurisprudencia/2259097/apelacao-civel-ac-350-ba-19983301000350-0/inteiroteor-100767490>. Acesso em: 5 ago. 2015.

85 BRASIL. Tribunal Regional Federal da Segunda Região. Resolução $\mathrm{n}^{\circ}$ 39, de 05 de abril de 2005. Disponível em: <http://www2. trf4.jus.br/trf4/controlador.php?acao=pagina_visualizar\&id_pagina $=147>$ Acesso em: 06 ago. 2015. Sobre o tema ver: DE FREITAS, Vladimir Passos. DE FREITAS, FREITAS, Vladimir Passos de; FREITAS, Dario Almeida Passos de. A proteção do meio ambiente na zona costeira. In: GRANZIERA, Maria Luiza Machado; GONÇALVES, Alcindo (Org.). Os problemas da zona costeira no Brasil e no mundo. Santos: Universitária Leopoldianum, 2012. p. 257-277. p. 270. 
A zona costeira é igualmente protegida por normas urbanísticas. As construções na borda da praia ou próximas a propriedades protegidas por seu patrimônio cultural são constantemente sancionadas. Há casos nos quais os tribunais autorizaram a demolição de quiosques construídos nas praias ${ }^{86}$ ou próximos a propriedades protegidas pelo patrimônio cultural ${ }^{87}$. No primeiro, a demolição dos quiosques foi autorizada pelo tribunal, porque sua construção ocorreu sem considerar nenhuma das normas urbanísticas da municipalidade nem o regime dos terrenos de marinha. $\mathrm{Na}$ decisão, o juiz mencionou a obrigação dos Municípios de seguir ${ }^{88}$ "as linhas e diretrizes do Projeto Orla, ${ }^{89}$ que tem por finalidade a elaboração e a implementação do Plano de Gestão Integrado do litoral municipalidades". No que concerne às propriedades protegidas por seu valor cultural, um caso interessante versa sobre a demolição de construções que foram realizadas em frente a um bar na zona costeira, situado ao lado do Museu Arqueológico de Itaipu, em Niterói. As construções bloqueavam o caminho que conduzia ao Museu. A decisão foi favorável à demolição com base em argumentos ambientais, em argumentos relacionados à inclusão dos terrenos de marinha como bens da União e no argumento do respeito, inclusive pela iniciativa privada, ao "projeto de urbanismo elaborado pela municipalidade". De acordo com a decisão,

[...] o Museu Arqueológico de Itaipu é um monumento culturalmente protegido pelo DecretoLei 25 de 30 de novembro de 1937, cujo artigo 30 proíbe todas as construções nas proximidades do prédio que possam reduzir sua visibilidade ${ }^{90}$.

86 BRASIL. Tribunal Regional Federal da Segunda Região. Ação Cível. AC n. ${ }^{\circ}$ 620555. Rio de Janeiro, 27 de outubro de 2014.

87 BRASIL. Tribunal Regional Federal da Segunda Região. Ação Cível. $A C n{ }^{\circ}{ }^{\circ} 382728$. Quinta turma especializada, Rio de Janeiro, 10 de novembro de 2010.

88 "Sustenta que, ao agir dessa forma, o Município de Araruama atendeu às diretrizes do Projeto Orla, que tem como finalidade elaborar e implementar um Plano de Gestão Integrada - PGI da orla marítima e fluvial dos Municípios brasileiros".

89 BRASIL. Ministério do Meio Ambiente. Projeto Orla. Disponível em: <http://www.mma.gov.br/gestao-territorial/gerenciamentocosteiro/projeto-orla>. Acesso em: 18 out. 2014.

90 P. 8 da decisão: "Nos termos da Informação no 235/93 apresentada pelo IPHAN, à fl. 290, aquela construção [...] é prejudicial à ambiência do monumento tombado, pois contraria o projeto urbanístico elaborado para o local pela prefeitura (o qual se encontra em análise por este Instituto). O Museu de Arqueologia de Itaipu é um monumento tombado (cf. Ofício 67/95, do IPHAN, à fl. 291), sendo a sua proteção conferida pelo Decreto-lei 25, de 30 de novembro de 1937 (que organiza a proteção do patrimônio histórico e artístico nacional), cujo art. 18 veda qualquer construção, na vizinhança de imóveis tombados, que lhes impeça ou reduza a visibilidade, sob pena de retirada ou destruição e multa de $50 \%$ do valor das obras
No contexto da elaboração dos Planos de Gestão Integrada da Zona Costeira, que se insere na competência das municipalidades, os parâmetros ambientais, sociais e econômicos devem ser abordados de forma conjunta. Por exemplo, os critérios de proteção do meio ambiente deveriam considerar as áreas protegidas, as condições de utilização das praias, a presença de lixo e a possibilidade de exploração de recursos naturais ${ }^{91}$. Parâmetros sociais, como a presença de comunidades tradicionais, o turismo, a urbanização, os serviços de fornecimento de água também devem ser considerados, assim como critérios econômicos como a especulação imobiliária, os usos agrícola, mineral, petrolífero, a pesca, a navegação, as atividades portuárias e o turismo. Os indicadores de qualidade da gestão das zonas costeiras pelos Municípios poderiam ser baseados em parâmetros nacionais ${ }^{92}$. Os recursos financeiros deveriam ser distribuídos às municipalidades de maneira proporcional à efetivação dos Planos municipais de Gestão Integrada ${ }^{93}$.

\section{Considerações finais}

A análise realizada demonstrou alguns dos entraves de cunho institucional e normativo que o planejamento da ocupação sustentável da zona costeira brasileira enfrenta, tanto em sua faixa marítima quanto em sua faixa terrestre. Contribuiu, ainda, com a identificação de imprecisões conceituais que não são devidamente aclaradas pelos poderes competentes, tais como bem comum de uso do povo, patrimônio nacional e bem da União. Constata-se, portanto, limites consideráveis no âmbito

proibidas". BRASIL. Tribunal Regional Federal da Segunda Região. Apelação Civil. AC 200351020031062 RJ 2003.51.02.003106-2. Quinta Turma Especializada. Apelante: Bar e Restaurante Ancora Ltda. Apelado: Ministério Público Federal. Relator: Des. Federal Fernando Marques. Rio de Janeiro, 2010. Disponível em: <http:// trf-2.jusbrasil.com.br/jurisprudencia/17549680/apelacao-civel-ac200351020031062-rj-20035102003106-2/inteiro-teor-103757871>. Acesso em: 06 ago. 2015.

91 ARZABE, Jorge. Gestão da zona costeira e os terrenos de marinha. 2011. 60 f. Trabalho de Conclusão de Curso (Especialista) - Curso Intensivo de Pós-Graduação em Administração Pública, Programa FGV Management, Fundação Getúlio Vargas, Brasília, 2011. p. 26. 92 ARZABE, Jorge. Gestão da zona costeira e os terrenos de marinha. 2011. 60 f. Trabalho de Conclusão de Curso (Especialista) - Curso Intensivo de Pós-Graduação em Administração Pública, Programa FGV Management, Fundação Getúlio Vargas, Brasília, 2011. p. 28. 93 ARZABE, Jorge. Gestão da zona costeira e os terrenos de marinha. 2011. 60 f. Trabalho de Conclusão de Curso (Especialista) - Curso Intensivo de Pós-Graduação em Administração Pública, Programa FGV Management, Fundação Getúlio Vargas, Brasília, 2011. p. 31. 
administrativo, legislativo e judiciário, nos entes da federação, para atuar na gestão da zona costeira. Esses limites, enquanto não superados, permitirão a ocupação indevida e insustentável da zona costeira brasileira.

Com relação aos limites institucionais, apesar do amplo número de entes competentes para administrar a proteção ambiental da zona costeira, não há dispositivos claros sobre a competência de cada um no que concerne à zona costeira.

Espera-se que a LC 140/2001 contribua com interpretações mais precisas quanto às competências de cada ente federativo. As competências da Autoridade Marítima para a faixa marítima da zona costeira também não são precisas e acabam por centralizar a gestão dessa área para a atividade da navegação. O que deve ser priorizado é a gestão dos usos múltiplos da zona costeira, o que ainda não pode ser vizualizado no Brasil.

No que tange aos limites normativos, a imprecisão de conceitos gerais relacionados à zona costeira, como bem de uso comum do povo, bem da União e patrimônio nacional resultam em uma insegurança jurídica para a região. Essa imprecisão de dispositivos normativos vulnerabiliza os biomas característicos da zona costeira, além de dificultar o controle do que pode ou não pode ser construído na zona costeira.

Diante desse contexto, parece mais adequado resolver primeiramente os problemas de interpretação dos conceitos, de definições e de imprecisões para, em seguida, realizar a gestão sustentável e integrada da zona costeira e apenas posteriormente integrar essa gestão à planificação do espaço marinho brasileiro.

\section{REFERÊNCIAS}

AGENCIA NACIONAL DE TRANSPORTES AQUAVIARIOS. PGO Plano Geral de Outorgas: apresentações. Disponível em: <http://www.antaq.gov.br/ portal/Portos_PGO.asp>. Acesso em 10 set. 2014.

ALMEIDA, José Mauro de Lima O. de. Terrenos de marinha, proteção ambiental e as cidades. Belém: Paka-Tatu, 2008.

ARZABE, Jorge. Gestão da zona costeira e os terrenos de marinha. 2011. 60 f. Trabalho de Conclusão de Curso (Especialista) - Curso Intensivo de Pós-Graduação em Administração Pública, Programa FGV Management, Fundação Getúlio Vargas, Brasília, 2011.
BRASIL. Câmara dos Deputados. Decreto n ${ }^{\circ} 74.557$, de 12 de setembro de 1974. Disponível em: <http://www. planalto.gov.br/ccivil_03/decreto/Antigos/D74557. htm>. Acesso em: 05 ago. 2015.

BRASIL. Câmara dos deputados. Projeto de Emenda Constitucional $n^{0}$ 39, de 2011. Disponível em: <http://www. camara.gov.br/proposicoesWeb/fichadetramitacao?idP roposicao=508965> . Acesso em 06 ago. 2015.

BRASIL. Câmara dos deputados. Projeto de Emenda Constitucional $n^{\circ}$ 53, de 2007. Disponível em: <http://www. camara.gov.br/proposicoesWeb/fichadetramitacao?idP roposicao $=349704>$. Acesso em 06 ago. 2015.

BRASIL. Câmara dos Deputados. Projeto de Emenda Constitucional no 603, de 1998. Disponível em: <http:/ / www2.camara.leg.br/atividade-legislativa/comissoes/ comissoes-temporarias/especiais/52a-legislatura/pec603-98-terrenos-de-marinha>. Acesso em 06 ago. 2015.

BRASIL. Câmara dos deputados. Projeto de lei ñ 1082, de 2011. Disponível em: <http://www.camara.gov. br/proposicoesWeb/fichadetramitacao?idProposic ao $=498619>$. Acesso em 06 ago. 2015.

BRASIL. Câmara dos deputados. Projeto de lei ñ 1117 , de 2011. Disponível em: <http://www.camara.gov. br/proposicoesWeb/fichadetramitacao?idProposic ao $=498959>$. Acesso em 06 ago. 2015.

BRASIL. Câmara dos deputados. Projeto de lei $n^{\circ}$ 6623, de 2006. Disponível em: <http://www.camara.gov. br/proposicoesWeb/fichadetramitacao?idProposic ao $=313821>$. Acesso em 06 ago. 2015.

BRASIL. Câmara dos deputados. Projeto de lei n 6752, de 2010. Disponível em: <http://www.camara.gov. $\mathrm{br} /$ proposicoesWeb/fichadetramitacao?idProposic ao $=465829>$. Acesso em 06 ago. 2015.

BRASIL. Câmara dos Deputados. Projeto de lei 6969 de 17 de dezembro de 2013. Disponível em: <http://www. camara.gov.br/proposicoesWeb/fichadetramitacao?idP roposicao=604557>. Acesso em: 5 ago. 2015.

BRASIL. Comissão Interministerial para os Recursos do Mar. Resolução no 01, de 21 de novembro de 1990, Disponível em: <https://www.mar.mil.br/secirm/document/ataseresolucoes/resolucao-1-1994.pdf $>$. Acesso em: 05 ago. 2015.

BRASIL. Constituição (1988). Constituição da República Federativa do Brasil. Disponível em: <http://www. planalto.gov.br/ccivil_03/constituicao/constituicao. 
htm>. Acesso em: 05 ago. 2014.

BRASIL. Decreto n $n^{0} 5.300$, de 07 de dezembro de 2004. Disponível em: <http://www.planalto.gov.br/ccivil_03/_ ato2004-2006/2004/decreto/D5300.htm>. Acesso em: 10 jul. 2014.

BRASIL. Decreto ñ. 5.377 de 23 de fevereiro de 2005. Disponível em: <http://www.planalto.gov.br/ccivil_03/_ Ato2004-2006/2005/Decreto/D5377.htm>. Acesso em: 06 ago. 2015.

BRASIL. Decreto n ${ }^{\circ}$ 6.678, de 8 de dezembro de 2008. Disponível em: <http://www.planalto.gov.br/ccivil_03/_Ato2007-2010/2008/Decreto/D6678.htm>. Acesso em: 05 ago. 2015.

BRASIL. Decreto-lei ñ 9.760, de 05 de setembro de 1946. Disponível em: <http://www.planalto.gov.br/ccivil_03/ decreto-lei/del9760.htm>. Acesso em: 05 ago. 2015.

BRASIL. Lei Complementar $n^{\circ} 140$, de 08 de dezembro de 2011. Disponível em: <http://www.planalto.gov.br/ccivil_03/leis/lcp/Lcp140.htm>. Acesso em:10 nov.2014.

BRASIL. Lei no 6.938, de 31 de agosto de 1981. Disponível em: <http://www.planalto.gov.br/ccivil_03/leis/16938. htm>. Acesso em: 4 out. 2014.

BRASIL. Lei n 7.661 de 16 de maio de 1998. Disponível em: <http://www.planalto.gov.br/ccivil_03/leis/17661. htm>. Acesso em: 04 ago. 2015.

BRASIL. Lei ño 8.617 de 04 de janeiro de 1993. Disponível em: <http://www.planalto.gov.br/ccivil_03/leis/18617. htm>. Acesso em: 05 out. 2014.

BRASIL. Lei no 9.966 de 28 de abril de 2000. Disponível em: <http://www.planalto.gov.br/ccivil_03/leis/ L9966.htm>. Acesso em: 4 out. 2014.

BRASIL, Lei $n^{0}$ 10.406, de 10 de janeiro de 2002. Disponível em: <http://www.planalto.gov.br/ccivil_03/ leis/2002/110406.htm >. Acesso em: 05 ago. 2015. Artigo 99 e seguintes. BRASIL. Lei no 7.661 de 16 de maio de 1998. Disponível em: <http://www.planalto.gov.br/ ccivil_03/leis/17661.htm>. Acesso em: 04 ago. 2015.

BRASIL. Lei $n^{\circ} 12.651$ de 25 de maio de 2012. Disponível em: < http://www.planalto.gov.br/ccivil_03/_ Ato2011-2014/2012/Lei/L12651.htm\#art83>. Acesso em: agosto 2014.

BRASIL. Marinha do Brasil. Normas da autoridade maritima para obras, dragagens, pesquisa e lavra de minerais sob, sobre $e$ às margens das águas jurisdicionais brasileiras: NORMAM
11/DPC. 2003. Disponível em: <https://www3.dpc. mar.mil.br/normam/N_11/normam11.pdf $>$. Acesso em: 05 ago. 2015.

BRASIL. Ministério de Minas e Energia. Departamento Nacional de Produção Mineral. Portaria no 441, de 11 de dežembro de 2009. Disponível em: <http://www2.dnpm. gov.br $/$ conteudo.asp?IDSecao $=67 \&$ IDPagina $=84 \&$ ID Legislacao $=589>$. Acesso em: 5 ago. 2015.

BRASIL. Ministério do Meio Ambiente. Limites da Zona Costeira. Disponível em: <http://www.mma.gov. $\mathrm{br} /$ gestao-territorial/gerenciamento-costeiro/a-zona-

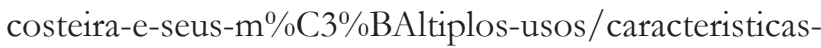
da-zona-costeira>. Acesso em: 09 nov. 2014.

BRASIL. Ministério do Meio Ambiente. Plano Nacional de Gerenciamento Costeiro (PNGC II). 1997. Disponível em: <http://www.mma.gov.br/images/arquivo/80033/0.PNGC-II97\%20Resolucao05_97.CIRM. pdf $>$. Acesso em: 15 out. 2014.

BRASIL. Ministério do Meio Ambiente. Projeto Orla. Disponível em: <http://www.mma.gov.br/gestao-territorial/gerenciamento-costeiro/projeto-orla>. Acesso em: 18 out. 2014.

BRASIL. Ministério do Meio Ambiente. Zona Costeira e Marinha. Disponível em: <http://www.mma.gov.br/ biodiversidade/biodiversidade-aquatica/zona-costeirae-marinha>. Acesso em: 15 out. 2014.

BRASIL. Senado Federal. Projeto de Emenda Constitucional $n^{0}$ 56, de 2009. Disponível em: <http://www. senado.leg.br/atividade/materia/detalhes.asp?p_cod_ mate $=95166>$. Acesso em 06 ago. 2015 .

BRASIL. Senado Federal. Projeto de Emenda Constitucional $n^{\circ}$ 256, de 2011. Disponível em: <http://www. senado.gov.br/atividade/materia/detalhes.asp?p_cod_ mate $=100239>$. Acesso em 06 ago. 2015 .

BRASIL. Superior Tribunal de Justiça. Recurso Especial. Resp no 1183546/ES. Segunda Turma. Recorrente: S/A A Gazeta e Outros. Recorrido: União. Relator: Min. Mauro Campbel Marques. Brasília, 08 setembro de 2010. Disponível em: <http://stj.jusbrasil. com.br/jurisprudencia/16376533/recurso-especialresp-1183546-es-2010-0040958-3/relatorio-e-voto-16978062>. Acesso em: 05 ago. 2015.

BRASIL. Supremo Tribunal Federal. Medida Cautelar na Ação Direta de Inconstitucionalidade. ADI 4264 MC/PE. Tribunal Pleno. Requerente: Assembléia Le- 
gislativa do Estado de Pernambuco. Requerido: Presidente da República. Relator: Min. Ricardo Lewandowski. Brasília, 16 de março de 2011. Disponivel em: <http://redir.stf.jus.br/paginadorpub/paginador. jsp?docTP $=$ AC\&docID $=623508>$. Acesso em: 05 ago. 2015.

BRASIL. Supremo Tribunal Federal. Recurso Extraordinário. RE 134297 SP. Primeira Turma. Recorrente: Estado de São Paulo. Recorridos: Paulo Ferreira Ramos e Cônjuge. Relator: Min. Celso de Mello. Brasília, 13 de junho de 1995. Disponível em<http://stf.jusbrasil. com.br/jurisprudencia/745994/recurso-extraordinario-re-134297-sp>. Acesso em: 05 ago. 2015.

BRASIL. Tribunal Regional Federal da Primeira Região. Agravo de Instrumento. AG 183530620124010000 MA 0018353-06.2012.4.01.0000. Quinta Turma. Agravante: Delman Rodrigues Incorporações Ltda. Agravado: Ministério Público Federal. Relator: Des. Souza Prudente. Brasília,31 de setembro de 2013. Disponível em: < http:/ / trf-1.jusbrasil.com.br/jurisprudencia/24138498/ agravo-de-instrumento-ag-183530620124010000-ma0018353-0620124010000-trf1>. Acesso em: 5 ago. 2015.

BRASIL. Tribunal Regional Federal da Primeira Região. Apelação Cível. AC 350 BA 1998.33.01.0003500. Sexta Turma. Apelante: Golden Beach Hotel Ltda. Apelado: União Federal. Relator(a): Des. Federal Maria Isabel Gallotti Rodrigues. Brasília, 31 de maio de 2014. Disponível em: <http://trf-1.jusbrasil. com.br/jurisprudencia/2259097/apelacao-civel-ac350-ba-19983301000350-0/inteiro-teor-100767490>. Acesso em: 5 ago. 2015.

BRASIL. Tribunal Regional Federal da Quarta Região. Acordão. Processo 1998.7204.003633-7. Terceira Turma. Relator: Des. Federal Fernando Quadros. Porto Alegre, 30 de novembro de 2010.

BRASIL. Tribunal Federal da Quarta Região. Apelação Cível. AC 5000228-69.2010.404.7216/SC. Vice-Presidência. Apelante: Orlando Ivã larionoff. Apelado: IBAMA. Relator: Des. Federal Luiz Fernando Wowk Pentead. Porto Alegre, 02 de outubro de 2014. Disponível em: <http://trf-4.jusbrasil.com. br/jurisprudencia/143419040/apelacao-civel-ac50002286920104047216-sc-5000228-6920104047216/ inteiro-teor-143419116>. Acesso em: 5 ago. 2015.

BRASIL. Tribunal Federal da Quarta Região. Re- curso Especial em Apelação Cível. $A C n^{0} 0000959-$ 87.2009.404.7216/SC. Terceira Turma. Recorrente: IBAMA. Recorrido: Territorial Garopaba Ltda. Relator(a): Des. Maria Lúcia Luz Leiria. Porto Alegre, 19 de agosto de 2012. Disponível em: <http://www. jusbrasil.com.br/diarios/64854576/trf-4-judicial-1701-2014-pg-75>. Acesso em: 5 ago. 2015.

BRASIL. Tribunal Regional Federal da Quarta Região. Apelação Cível. AC 0004571-88.2003.404.7201/SC. Terceira Turma. Apelante IBAMA; Ministério Público Federal. Apelado: Município de Itapoá/SC. Relator (a): Des. Federal Maria Lúcia Luz Leiria. Porto Alegre, 1 de fevereiro de 2011. Disponível em: < http://trf-4. jusbrasil.com.br/jurisprudencia/18575379/apelacaocivel-ac-7201-sc-0004571-8820034047201-trf4/inteiroteor-18575380>. Acesso em: 5 ago. 2015.

BRASIL. Tribunal Regional Federal da Quinta Região. Agravo de Instrumento. AGTR 107968/CE - 000966867.2010.4.05.0000. Primeira Turma. Agravante: Ministério Público Federal. Agravado: Construtora Waldyr Diogo Ltda e outros. Relator : Des. Federal Francisco Cavalcanti. Recife, 03 de maio de 2012. Disponível em: $<$ http://www.jusbrasil.com.br/diarios/37330603/trf5-jud-25-05-2012-pg-57>. Acesso em: 5 ago. 2015.

BRASIL. Tribunal Regional Federal da Segunda Região. Ação Cível. $A C$ n. ${ }^{\circ} 487271$. Sexta Turma especializada. Rio de Janeiro, em 19 de março de 2012.

BRASIL. Tribunal Regional Federal da Segunda Região. Ação Cível. AC 585795. Sétima turma especializada. Rio de Janeiro, 30 de outubro de 2013.

BRASIL. Tribunal Regional Federal da Segunda Região. Ação Cível. $A C$ n. ${ }^{\circ}$ 620555. Rio de Janeiro, 27 de outubro de 2014.

BRASIL. Tribunal Regional Federal da Segunda Região. Ação Cível. $A C$ n. ${ }^{\circ} 382728$. Quinta turma especializada, Rio de Janeiro, 10 de novembro de 2010.

BRASIL. Tribunal Regional Federal da Segunda Região. Agravo de Instrumento. AG 2012.02.01.0048593. Quinta Turma Especializada. Agravante: IBAMA. Agravado: Thiago Cunha de Almeida. Relator: Des. Federal Marcus Abraham. Rio de Janeiro, 29 de janeiro de 2013. Disponível em: <http://trf-2.jusbrasil.com.br/ jurisprudencia/23376162/ag-agravo-de-instrumentoag-201202010048593-trf2/inteiro-teor-111700881>. Acesso em: 5 ago. 2015. 
BRASIL. Tribunal Regional Federal da Segunda Região. Agravo de Instrumento. AG 2012.02.01.0057247. Quinta Turma Especializada. Agravante: Ministério Publico Federal. Agravado: Aluísio Leal Santos. Relator: Des. Federal. Marcus Abraham. Rio de Janeiro, 28 de maio de 2013. Disponível em: < http://trf-2. jusbrasil.com.br/jurisprudencia/23610800/ag-agravode-instrumento-ag-201202010057247-trf2/inteiro-teor-111757639>. Acesso em: 5 ago. 2015.

BRASIL. Tribunal Regional Federal da Segunda Região. Agravo de Instrumento. AG 2012.02.01.0048593. Quinta Turma Especializada. Agravante: IBAMA. Agravado: Thiago Cunha de Almeida. Relator: Des. Federal Marcus Abraham. Rio de Janeiro, 29 de janeiro de 2013. Disponível em: < http://trf-2.jusbrasil.com.br/ jurisprudencia/23376162/ag-agravo-de-instrumentoag-201202010048593-trf2/inteiro-teor-111700881>. Acesso em: 5 ago. 2015.

BRASIL. Tribunal Regional Federal da Segunda Região. Apelação Civil. AC 200351020031062 RJ 2003.51.02.003106-2. Quinta Turma Especializada. Apelante: Bar e Restaurante Ancora Ltda. Apelado: Ministério Público Federal. Relator: Des. Federal Fernando Marques. Rio de Janeiro, 2010. Disponível em: < http:/ / trf-2.jusbrasil.com.br/jurisprudencia/17549680/apelacao-civel-ac-200351020031062-rj-20035102003106-2/ inteiro-teor-103757871>. Acesso em: 06 ago. 2015.

BRASIL. Tribunal Regional Federal da Segunda Região. Apelação Cível. AC 200651080008781. Sexta Turma Especializada. Apelante: Denival da Silva Ferraz e outros. Apelado União Federal, Município de Araruama; IBAMA. Relator (a): Des. Federal Carmen Silvia Lima de Arruda. Rio de Janeiro, 31 de março de 2014. Disponível em: <http://trf-2.jusbrasil.com. br/jurisprudencia/25091049/ac-apelacao-civel-ac200651080008781 -trf2/inteiro-teor-120459970>. Acesso em: 5 ago. 2015.

BRASIL. Tribunal Regional Federal da Segunda Região. Apelação/Reexame Necessário. APELRE 200851020028899 RJ. Sexta Turma Especializada. Apelante: União Federal. Apelado: Leonardo Almendra Honorato e Outros. Relator (a). Des. Federal: Carmen Silvia Lima Arruda. Rio de Janeiro, de 2014. Disponível em: $\quad<$ http://trf-2.jusbrasil.com.br/jurisprudencia/160029380/apelacao-reexame-necessario-apelre200851020028899-rj/inteiro-teor-160029517>. Acesso em: 06 ago. 2015.
BRASIL. Tribunal Regional Federal da Segunda Região. Resolução no 39, de 05 de abril de 2005. Disponível em: $\quad<$ http://www2.trf4.jus.br/trf4/controlador. php?acao=pagina_visualizar\&id_pagina $=147>$ Acesso em: 05 ago. 2015.

BRASIL. Tribunal Regional Federal da Segunda Região. Apelação Civil. AC 200351020031062 RJ 2003.51.02.003106-2. Quinta Turma Especializada. Apelante: Bar e Restaurante Ancora Ltda. Apelado: Ministério Público Federal. Relator: Des. Federal Fernando Marques. Rio de Janeiro, 2010. Disponível em: < http:/ / trf-2.jusbrasil.com.br/jurisprudencia/17549680/apelacao-civel-ac-200351020031062-rj-20035102003106-2/ inteiro-teor-103757871>. Acesso em: 06 ago. 2015.

CEARÁ. Lei no 13.796, de 30 de junho de 2006. Institui a Política Estadual de Gerenciamento Costeiro, e o Plano Estadual de Gerenciamento Costeiro e dá outras providências. Disponível em: <http://www.al.ce.gov.br/ legislativo/legislacao5/leis2006/13796.htm>. Acesso em: 05 ago. 2015.

ESPÍRITO SANTO. Lei ñ 5.816, de 22 de dezembro de 1998. Institui o Plano Estadual de Gerenciamento Costeiro do Espírito Santo. Disponível em: <http://www. meioambiente.es.gov.br/web/Lei_5816.htm>. Acesso em: 05 ago. 2015.

FREITAS, Vladimir Passos de; FREITAS, Dario Almeida Passos de. A proteção do meio ambiente na zona costeira. In: GRANZIERA, Maria Luiza Machado; GONÇALVES, Alcindo (Org.). Os problemas da zona costeira no Brasil e no mundo. Santos: Universitária Leopoldianum, 2012. p. 257-277.

GRANZIERA, Maria Luiza Machado; GONÇALVES, Alcindo (Org.). Os problemas da zona costeira no Brasil e no mundo. Santos: Universitária Leopoldianum, 2012.

FREITAS, Mariana Almeida Passos de. Zona Costeira e Meio Ambiente. Curitiba: Jurua, 2005.

FREITAS, Vladimir Passos de; FREITAS, Dario Almeida Passos de. A proteção do meio ambiente na zona costeira. In: GRANZIERA, Maria Luiza Machado; GONÇALVES, Alcindo (Org.). Os problemas da zona costeira no Brasil e no mundo. Santos: Universitária Leopoldianum, 2012. p. 257-277.

GUERRA, Sérgio. Licenciamento Ambiental de Acordo com a LC 140/2011. Revista de Direito Ambiental, São Paulo, v. 17, n. 66, p. 153-179, abr./jun. 2012. 
LOITZENBAUER, Ester; MENDES, Carlos André Bulhões. A faixa terrestre da zona costeira e os recursos hídricos na região hidrográfica do Atlântico Sul. Revista de Gestão Costeira Integrada, Lisboa, v. 14, n. 1, p. 81-94, mar. 2014.

MACHADO, Paulo Affonso Leme. Direito ambiental brasileiro. 21 ed. São Paulo: Malheiros, 2012.

NOIN. Daniel. La population des littoraux du monde. L'information géographique, Paris, v. 63, n. 2, p. 65-73, 1999. Disponível em: < http://www.persee.fr/web/revues/home/prescript/article/ingeo_0020-0093_1999_ num_63_2_2632>. Acesso em: 4 ago. 2015.

RIO DE JANEIRO. Lei ñ 2.423, de 17 de agosto de 1995. Disciplina a pesca nos cursos d'água do Estado do Rio de Janeiro e adota outras providências Disponível em: $<$ http://gov-ri.jusbrasil.com.br/legislacao/150735/lei2423-95>. Acesso em: 05 ago. 2015.

RIO GRANDE DO SUL. Lei $n^{\circ} 11.886$, de 2 de janeiro de 2003. Dá nova redação ao artigo $1^{\circ}$. da Lei Estadual n. 8.676, de 14 de julho de 1988, que determina a obrigatoriedade de demarcação das áreas de pesca, lazer ou recreação, nos Municípios com orla marítima, lacustre e fluvial Disponível em: <http://www.legislacao.sefaz. rs.gov.br/Site/Document.aspx?inpKey=102719\&inpC odDispositive $=\&$ inpDsKeywords $=>$. Acesso em: 05 ago. 2015.

RUFINO, Gilberto d'Avila. Patrimônio costeiro e seus fundamentos jurídicos. In: MORAES, Antônio Carlos Robert; ZAMBONI, Adenilson (Org.). Subsidios para um projeto de gestão. Brasília: MMA, 2004. (Projeto Orla).

RUFINO, Gilberto d'Ávila. Royalties do petróleo e diretos dos Municípios produtores: elementos para análise e discussão.
Disponível em: <www.ijlitoral.org>. Acesso em: nov., 2012.

RUFINO, Gilberto d'Ávila. Royalties do petróleo para Municipios costeiros. Disponível em: <www.ijlitoral.org>. Acesso em: nov., 2012.

SÃO PAULO. Lei no 10.019 de 3 de julho de 1998. Dispõe sobre o Plano Estadual de Gerenciamento Costeiro e dá outras providências. Disponível em: <http://www. al.sp.gov.br/repositorio/legislacao/lei/1998/lei-1001903.07.1998.html>. Acesso em: 05 ago. 2015.

SÃO PAULO. Lei no 11.165, de 27 de junho de 2002. Institui o Código de Pesca e Aqüicultura do Estado. Disponível em: <http://www.al.sp.gov.br/repositorio/legislacao/lei/2002/lei-11165-27.06.2002.html>. Acesso em: 05 ago. 2015.

SILVA, Solange Teles da. Direito fundamental ao meio ambiente ecologicamente equilibrado: avanços e desafios. Revista de Direito Ambiental, São Paulo, v. 12, n. 48, p. 225-245, out./dez. 2007.

SILVA, Solange Teles da. Planejamento urbano na Zona Costeira. In: Compedi. In: CONGRESSO NACIONAL DO CONPEDI, 14., 2005, Fortaleza. Anais eletrônico... Manaus: CONPEDI, 2006. Disponível em: http://www. conpedi.org.br/manaus/arquivos/anais/XIVCongresso/151.pdf. Acesso em: 4 ago. 2015.

SODRÉ, Marcelo Gomes. Zoneamento Ecológicoeconômico e zoneamento costeiro: algumas polêmicas jurídicas In: GRANZIERA, Maria Luiza Machado; GONÇALVES, Alcindo (Org.). Os problemas da zona costeira no Brasil e no mundo. Santos: Universitária Leopoldianum, 2012. p. 116-141. 
Para publicar na Revista de Direito Internacional, acesse o endereço eletrônico www.rdi.uniceub.br ou www.brazilianjournal.org.

Observe as normas de publicação, para facilitar e agilizar o trabalho de edição. 